\title{
Shiga Toxins: An Update on Host Factors and Biomedical Applications
}

\author{
Yang Liu $1,2,3, * \mathbb{C}$, Songhai Tian ${ }^{2,3} \mathbb{D}$, Hatim Thaker ${ }^{2,3}$ and Min Dong ${ }^{2,3, *}$ \\ 1 Department of Nephrology, The First Hospital of Jilin University, Changchun 130021, China \\ 2 Department of Urology, Boston Children's Hospital, Boston, MA 02115, USA; \\ Songhai.Tian@childrens.harvard.edu (S.T.); hatim.thaker@childrens.harvard.edu (H.T.) \\ 3 Department of Microbiology and Department of Surgery, Harvard Medical School, Boston, MA 02115, USA \\ * Correspondence: ly840604@jlu.edu.cn (Y.L.); min.dong@childrens.harvard.edu (M.D.)
}

check for updates

Citation: Liu, Y.; Tian, S.; Thaker, H.; Dong, M. Shiga Toxins: An Update on Host Factors and Biomedical

Applications. Toxins 2021, 13, 222.

https://doi.org/10.3390/

toxins13030222

Received: 18 February 2021

Accepted: 15 March 2021

Published: 18 March 2021

Publisher's Note: MDPI stays neutral with regard to jurisdictional claims in published maps and institutional affiliations.

Copyright: (c) 2021 by the authors. Licensee MDPI, Basel, Switzerland. This article is an open access article distributed under the terms and conditions of the Creative Commons Attribution (CC BY) license (https:/ / creativecommons.org/licenses/by/ $4.0 /)$.

\begin{abstract}
Shiga toxins (Stxs) are classic bacterial toxins and major virulence factors of toxigenic Shigella dysenteriae and enterohemorrhagic Escherichia coli (EHEC). These toxins recognize a glycosphingolipid globotriaosylceramide (Gb3/CD77) as their receptor and inhibit protein synthesis in cells by cleaving $28 \mathrm{~S}$ ribosomal RNA. They are the major cause of life-threatening complications such as hemolytic uremic syndrome (HUS), associated with severe cases of EHEC infection, which is the leading cause of acute kidney injury in children. The threat of Stxs is exacerbated by the lack of toxin inhibitors and effective treatment for HUS. Here, we briefly summarize the Stx structure, subtypes, in vitro and in vivo models, Gb3 expression and HUS, and then introduce recent studies using CRISPR-Cas9-mediated genome-wide screens to identify the host cell factors required for Stx action. We also summarize the latest progress in utilizing and engineering Stx components for biomedical applications.
\end{abstract}

Keywords: Shiga toxin; EHEC; Shigella; hemolytic uremic syndrome; Gb3; LAPTM4A; TM9SF2; immunotoxin; bacterial toxins; toxins

Key Contribution: We summarize the latest progress in the identification of host factors for Shiga toxins and biomedical applications of Shiga toxins.

\section{Introduction}

Shiga toxin (Stx) was named after Japanese microbiologist Kiyoshi Shiga, who identified and characterized Shigella dysenteriae in 1897 [1]. Among Shigella dysenteriae strains, serotype 1 is the toxigenic one that expresses Stx [2]. In 1977, a cytotoxic toxin from Escherichia coli (E. coli) isolates was discovered by Konowalchuck et al., initially named verotoxin or E. coli cytotoxin for its ability to kill cultured Vero cells [3]. By the early 1980s, $\mathrm{O}^{\prime}$ Brien et al. recognized that $E$. coli isolates express toxins highly similar to Stx; they called them Shiga-like toxins and designated the E. coli isolates Shiga-like toxin-producing E. coli (STEC) [4]. Among STEC, the strains associated with human diseases are also known as enterohemorrhagic E. coli (EHEC). It was soon realized that these toxins belong to the same Stx family and can be divided into two serotypes: Stx1 is almost identical to the prototype Stx in Shigella dysenteriae, while Stx2 shares $\sim 56 \%$ protein sequence identity with Stx [5].

Each year, in the United States, there are approximately 265,000 cases of EHEC infection [6], which usually starts with diarrhea and can develop into dysentery and hemorrhagic colitis. In severe cases, life-threatening complications such as hemolytic uremic syndrome (HUS) and neurological disorders can occur. HUS is most commonly associated with EHEC serotype O157:H7 infections, and Stx is the major cause [7]. HUS has the highest incidence in children and the elderly $[8,9]$ and is the major reason for acute kidney injury in children [10]. Patients have typically developed irreversible vascular damage by the time symptoms appear, and there is no specific treatment [7]. 
Investigations over the past 40 years have elucidated the molecular mechanism underlying the toxicity of Stx, established its central role in pathogenesis, and shed light on many key cellular functions. Furthermore, Stx and Stx fragments have also been utilized as tools for biomedical applications. Many topics in Stx biology and applications have been covered by excellent in-depth reviews in recent years [9,11-22]. Here, we will briefly introduce the mode of action for Stx and then focus on the latest progress in identifying host factors and engineering Stx for biomedical applications.

\section{Stx Structure and Function}

Stx is an AB5 toxin, comprising an enzymatic A subunit (Stx-A, $32 \mathrm{kDa}$ ) and five identical B subunits (Stx-B, $7.7 \mathrm{kDa}$ ) that form a pentamer. The A subunit connects to the pentamer noncovalently by inserting its C-terminal region into the central hole $[23,24]$ (Figure 1). The A subunit is an RNA N-glycosidase, which inhibits protein synthesis by cleaving 28S ribosomal RNA [25-27]. The B subunit is responsible for binding to receptors. The glycosphingolipid globotriaosylceramide (Gb3, also known as CD77) is the major receptor of Stx [28]. Crystal structural studies using Stx1-B and a trisaccharide analog of Gb3 revealed three Gb3 binding sites per B subunit (Figure 1). Thus, one Stx can bind up to $15 \mathrm{Gb3}$ simultaneously [29]. After clustering Gb3 on cell surfaces, Stx is internalized by clathrin-dependent and -independent endocytosis pathways [30,31], retrogradely sorted into the trans-Golgi network (TGN) and further into the endoplasmic reticulum (ER), bypassing the late endocytic pathway [32-36]. The A subunit is further processed by host furin and furin-like proteases (cleaving between R251 and M252 of Stx 1 and between R250 and A251 of Stx2) into the enzymatic piece A1 $(27.5 \mathrm{kDa})$ and the linker piece A2 $(4.5 \mathrm{kDa})$, connecting to the B subunit. The A1 and A2 domains remain connected by a single disulfide bond, which is reduced within the ER. The A1 domain is then released from the ER into the cytosol through the ER-associated protein degradation (ERAD) pathway to inhibit protein synthesis $[14,37,38]$.


Figure 1. The structure of Shiga toxin: an A subunit, which is cleaved into an enzymatic piece A1 (colored brown) and a linker piece A2 (colored magenta), and five B subunits (PDB: 4M1U). The disulfide bond connecting A1 and A2 pieces is colored red. In the bottom view (right panel), three receptor binding sites on one B subunit (colored yellow) are shown.

\section{Stx Subtypes}

Stx 1 and Stx2 each have multiple subtypes classified based on protein sequence variations. Three subtypes of Stx1 (Stx1a, Stx1c, and Stx1d) and eleven subtypes of Stx2 (Stx2a-Stx2k) have been reported so far [39-42]. Some STEC strains express only one type of Stx, while others may express multiple types simultaneously [39]. Protein stability, toxin potency, receptor preference, symptom severity, and related host reservoirs may vary among subtypes $[39,43]$. For example, strains that produce Stx2a, Stx2c, and Stx2d are often associated with colitis and HUS in human infections. STEC producing Stx2b, Stx2e, Stx2f, and $S t \times 2 g$ are usually associated with animal infections, such as in deer, pigs, pigeons, and cattle $[17,41,44,45]$. Stx2e is the common subtype causing the edema disease of swine [46]. 
Strains producing Stx2f are frequently found in pigeons and other birds [47-49]. In 2018, Stx2h and Stx2i were identified in STEC strains isolated from wild marmots and shrimp, respectively $[40,50]$. Two additional new subtypes, Stx2j and Stx2k, have recently been reported but have yet to be broadly accepted. Stx2k was isolated from bacterial strains of various sources, including animals (goats and pigs), raw meat (beef and mutton), and human patients with diarrhea [41,42].

Stx1 and most Stx2 subtypes recognize the Gb3 receptor. However, Stx2e binds preferentially to globotetraosylceramide (Gb4), which is synthesized by adding N-acetylgalactosamine to Gb3 [51]. Toxicity differences among Stx subtypes are partially ascribed to differences in receptor binding, and it is believed that the low dissociation rate of Stx2a with receptors may lead to greater toxicity due to longer toxin uptake [52]. This may be one reason why Stx2a, among all Stx2 subtypes, is implicated in most HUS cases [53].

\section{In Vitro Cultured Human Cell Models and In Vivo Animal Models}

A variety of human cell lines and primary cells have been utilized in studying Stx, such as colorectal adenocarcinoma cell lines HT-29 [54], Caco-2 and HCT-8 [55], glomerular endothelial cells [56], renal tubular epithelial cells [57], vascular endothelial cells [58], cervical cancer HeLa cells [59], Burkitt lymphoma cells [60], and macrophage-like THP-1 Cells [61]. Some cell lines can be sensitized to Stx by ectopic expression of exogenous Gb3 synthase $[62,63]$.

Tian et al. recently reported that the bladder cancer cell line 5637 was the most sensitive to Stx among a group of human cancer cell lines, with toxin doses that induce $50 \%$ of cell death at 0.028 (Stx1) and 0.007 (Stx2) ng/mL, respectively [64]. This is because 5637 cells endogenously express high levels of Gb3 [64]. This cell line could serve as a convenient and sensitive human cell line model for investigating Stx action and developing Stx inhibitors.

The sensitivity of different cell lines to Stx depends not only on Gb3 expression levels but also on membrane microdomains, as well as other host factors involved in toxin trafficking [14,62,65-68]. For example, ACHN cells and Caki-2 cells, which are two human renal tubular adenocarcinoma cell lines, showed drastically different levels of sensitivity to Stx2: ACHN cells are highly sensitive while Caki-2 cells are not. Further analysis shows that they have similar Gb3 levels. RNA sequencing analysis of the genes differentially expressed by ACHN and Caki-2 cells identified RAB5A, TRAPPC6B, and YKT6 as host cell factors required for the high sensitivity of ACHN to Stx2 [68].

As EHEC infection occurs in the intestine, human intestinal organoids (HIOs) have recently been utilized as a physiologically relevant model to investigate the effects of Stx on human intestinal cells. HIOs can be derived from pluripotent stem cells or intestinal stem cells and represent the small intestinal tissues to which EHEC attaches [69,70]. Pradhan et al. showed that HIOs express Gb3 as well as the transcripts of Gb3 synthase. Injection of Stx2a into HIOs in vitro induced necrosis and the apoptotic death of cells. HIOs can also be transplanted into mice, providing a method to assess the impact of Stx on human intestinal tissues in vivo [71].

Various animal models have been established for studying EHEC infection and Stx [72], including mice, rats, infant rabbits, and nonhuman primates [12,16]. In mice, Gb3 expression has been reported in the cerebral cortex, the microvascular endothelial cells of the pia mater, and renal tubular capillaries. However, there is no expression in the renal vascular endothelium, and mice do not develop HUS with Stx injections [73,74]. A HUS model of C57BL/ 6 mice can be established using a combination of Stx2 and lipopolysaccharide (LPS) via intraperitoneal (i.p.) injection [75]. These mice develop thrombocytopenia, hemolytic anemia, as well as renal failure, similar to HUS presentation in humans [75]. Previous studies have suggested that the NLRP3 (NOD-, LRR-, and pyrin domain-containing protein 3) inflammasome pathway can be triggered by Stx, leading to proinflammatory IL- $1 \beta$ release and cell death [76]. However, this inflammasome activation was later found not to be mediated by Stx itself but by LPS contamination copurified with Stx [77]. Though EHEC 
cannot normally infect mice [78-81], an alternative model has been developed by expressing Stx in Citrobacter rodentium, a native mouse pathogen [82]. A recent study showed that LPS-mediated inflammasome responses are inhibited by Stx in Stx-expressing C. rodentium infection in a mouse model, suggesting that Stx contributes to suppression of host defense against bacteria [77].

In addition to mice, rats have also been utilized as a model. Stx i.p. injection causes acute tubular necrosis, polyuria, and reduced urinary osmolality in rats as well as an increase of aquaporin type 2 and $\beta 2$-microglobulin in urine, indicating the dysfunction of water reabsorption in proximal and collecting tubules [83]. Adult rats i.p. injected with culture supernatant from recombinant E. coli expressing Stx2 (sStx2) can develop watery diarrhea, thrombocytopenia, hemolytic anemia, glomerular thrombotic microangiopathy, and tubular injury, which may result from the combined effect of Stx2 and other bacterial factors in the culture supernatant [84]. However, due to the low expression of Gb3 in vascular endothelial cells in rodents, weaned rats treated with sStx2 show few glomerular thrombotic microvascular lesions associated with HUS, despite the observation of glomerular mesangial hyperplasia [85].

Gb3 is expressed in the colon of infant rabbits [86]. After oral administration of Stx2, three-day-old New Zealand white rabbits showed diarrhea and intestinal inflammation but no HUS symptoms [16]. Either intravenous injection of Stx2 $(1200 \mathrm{ng} / \mathrm{kg})$ or oral administration of EHEC can cause diarrhea as well as intestinal and renal histological damage in weaned Dutch Belted (DB) rabbits [87,88].

The distribution and expression of Gb3 in primates such as macaques and baboons may resemble that of humans [89-92]. A baboon model has been created by intravenous administration of Stx (50-200 ng/ kg), which elicited thrombocytopenia, microangiopathic hemolytic anemia, and glomerular damage, similar to what is observed in Stx-mediated HUS in humans [91,93].

\section{Gb3 Expression in Humans and Hemolytic Uremic Syndrome (HUS)}

In humans, Gb3 expression has been reported in renal epithelium and endothelium, microvascular endothelial cells in the lamina propria of the intestine, intestinal pericryptal myofibroblasts, and subpopulations of B-lymphocytes in germinal centers $[13,14]$. Gb3 has also been found in smooth muscle cells of the digestive tract, the urogenital system, the placenta $[94,95]$, endothelial cells, dorsal root ganglion cells in the peripheral nervous system [14,96], and endothelial cells and neurons in the central nervous system [14,97]. Gb3/CD77 is also known by two other names: (1) Burkitt lymphoma antigen, as it is found in many Burkitt lymphoma cancer cells [98], and (2) $\mathrm{P}^{\mathrm{k}}$ blood group antigen, which belongs to the human P1PK blood group system consisting of three glycosphingolipid antigens $\left(\mathrm{P}^{\mathrm{K}}, \mathrm{P} 1\right.$, and NOR). $\mathrm{P}^{\mathrm{K}}$ antigen is expressed in red blood cells in most individuals [14,94]. It has been suggested that Stx can bind to blood cells and cause complement-mediated hemolysis [99]. Interestingly, microvesicles shed by blood cells may contain Stx, which has been suggested to mediate the circulation and absorption of toxins into endothelial and epithelial cells in the kidney [100].

HUS is a severe thrombotic microangiopathy characterized by renal injury, microangiopathic hemolytic anemia, and thrombocytopenia [101]. HUS caused by EHEC infection is known as diarrhea-positive HUS (D+HUS) or typical HUS, while atypical HUS can be caused by other infections, complement disorders, or other genetic mutations [102]. EHECHUS initially presents with symptoms of hemorrhagic colitis and subsequently includes hemolytic anemia, thrombosis, and kidney injury, leading to weakness, shortness of breath, skin ecchymosis, oliguria, edema, hypertension, and serious neurological symptoms such as epilepsy [9].

Microvascular endothelial cell apoptosis induces edema, while platelet and fibrin accumulation can further impede blood flow $[103,104]$. Platelets are reduced, partly due to microthrombi deposition along the endothelial cell wall and consumption by the reticuloendothelial system [105]. Thrombocytopenia may also result from Stx binding to activated 
platelets and immature megakaryoblasts in the bone marrow, inducing their apoptosis $[106,107]$. Mechanical destruction of erythrocytes through damaged blood vessels leads to hemolytic anemia, which combines with reduced microcirculation to produce multisystem ischemia [104]. It has also been proposed that Stx-triggered host immune responses in the gut and activation of immune cells may be another key contributor to the development of HUS [108]. Current EHEC-HUS treatment relies on supportive therapy. This includes fluid resuscitation, correcting electrolyte abnormalities, and controlling hypertension [34]; blood transfusions and renal replacement therapy are often required $[105,109]$.

\section{Host Factors Recently Identified through CRISPR-Cas9 Screens}

The CRISPR (clustered regularly interspaced short palindromic repeats)-Cas9 system can be viewed as a form of acquired immune system in bacteria against invading genetic elements. Cas9 is an endonuclease that uses guide RNA sequences encoded in CRISPR to recognize and cleave specific target DNA [110]. This system has now become a powerful technological platform to easily modify genes in eukaryotic cells. In 2014, Shalem et al. and Wang et al. developed genome-scale CRISPR-Cas9-mediated knockout screening in human cells $[111,112]$. Using this powerful approach, four groups independently carried out genome-wide CRISPR-Cas9 mediated screens to identify Stx host factors [64,113-115]. Although different cell lines and guide RNA libraries were utilized, the host factors identified from these screens are largely involved in the biosynthesis of Gb3, indicating that recognition of Gb3 is the major rate-limiting step in Stx intoxication.

Multiple ER- and Golgi-localized enzymes are involved in the biosynthesis of Gb3 (Figure 2). Ceramide (Cer) is the precursor of glycosphingolipids. The de novo synthesis of Cer happens on the cytosolic side of the ER membrane. Serine palmitoyl transferase (SPT) complex catalyzes the conversion of serine and palmitoyl-CoA (Pal-CoA) into 3dihydrosphingosine (3-KDS). Then, 3-KDS is converted to dihydrosphingosine (DHS) under the catalysis of 3-ketodihydrosphingominol reductase (KDSR). A range of acyl-CoA with saturated or unsaturated fatty acid chains can be subsequently incorporated into DHS to produce dihydroceramide (DHC). This step is catalyzed by ceramide synthase family enzymes (CERS). DHC is further oxidized to Cer by dihydroceramide $\Delta 4$-desaturases (DEGS). The glycosylation of Cer occurs on Golgi. First, one glucose residue is transferred onto Cer to produce glucosylceramide (GlcCer). This reaction is catalyzed by ceramide glucosyltransferase (UGCG) on the cytosolic side of cis-Golgi. Then, GlcCer is flipped into the lumen side and transported to the trans-Golgi. Two galactose residues are transferred to GlcCer to produce lactosylceramide (LacCer) and $\mathrm{Gb3}$ sequentially. These steps are catalyzed by $\beta$-1,4-galactosyltransferase 5 (B4GALT5) and the Gb3 synthase known as $\alpha-1,4$-galactosyltransferase (A4GALT), respectively [116-118]. SLC35A2 (UDP-galactose translocator) transports active galactose into the lumen of Golgi [64].

In 2018, Tian et al. reported genome-wide CRISPR-based loss-of-function screens for Stx1 and Stx2 using 5637 cells [64]. The same year, Pacheco et al. performed a screen for EHEC infection using HT29 cells [113]. In 2019 and 2020, two more screens for Stx using HeLa cells were published [114,115]. All four screens identified major players in the Gb3 biosynthesis pathway, such as A4GALT, SPTSSA, UGCG, B4GALT5, and SLC35A2. Three novel factors were then identified: LAPTM4A (lysosomal-associated protein transmembrane 4 alpha), TMEM165 (transmembrane protein 165), and TM9SF2 (transmembrane 9 superfamily member 2). In addition, the screen by Majumder et al. also identified aryl hydrocarbon receptor (AHR), a ligand-activated transcription factor, which might be required for the expression of several genes involved in the Gb3 biosynthesis pathway [115]. Tian et al. further carried out parallel screens using the plant toxin ricin, whose trafficking pathway and mode of action are similar to those of Stx but utilizes a broad range of glycans as receptors. The results indicate that LAPTM4A is specific to Stx, whereas TMEM165 and TM9SF2 are also required for ricin [64]. 


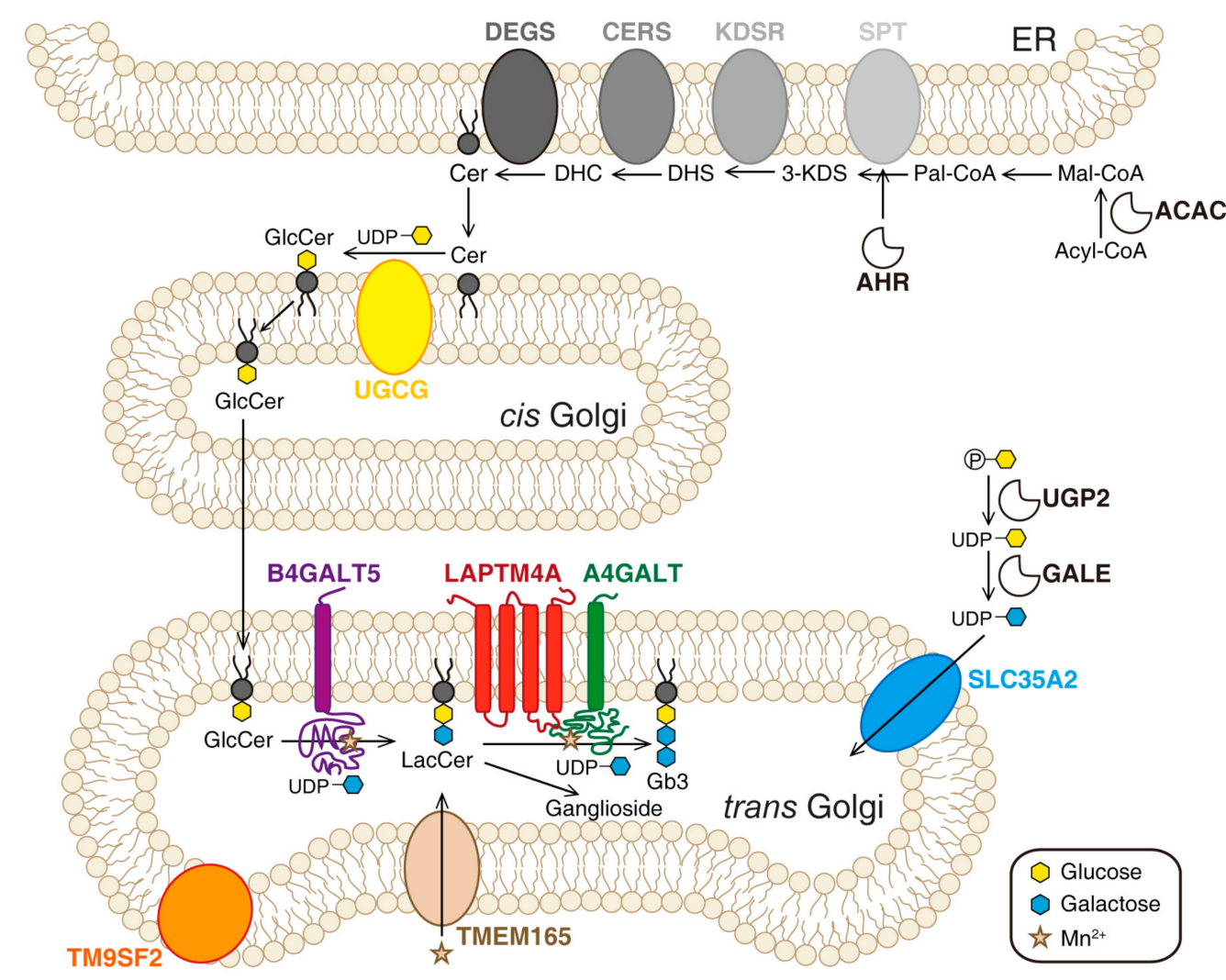

Figure 2. CRISPR (clustered regularly interspaced short palindromic repeats)/Cas9 screens identified genes involved in Gb3 biosynthesis, with a schematic diagram of the Gb3 biosynthesis pathway and a summary of the top genes identified in CRISPR/Cas9 screens. Cer: ceramide. ACACA: acetyl-CoA carboxylase alpha. Acyl-CoA: acetyl-CoA. Mal-CoA: malonyl-CoA. Pal-CoA: palmitoyl-CoA. SPT: serine palmitoyl transferase complex. 3-KDS: 3-dihydrosphingosine. DHS: dihydrosphingosine. KDSR: 3-ketodihydrosphingominol reductase. DHC: dihydroceramide. CERS: ceramide synthase family enzymes. DEGS: dihydroceramide $\Delta 4$-desaturases. GlcCer: glucosylceramide. UGCG: ceramide glucosyltransferase. LacCer: lactosylceramide. B4GALT5: $\beta$-1,4-galactosyltransferase 5. A4GALT: $\alpha$-1,4-galactosyltransferase. UGP2: UDPglucose pyrophosphorylase 2. GALE: UDP-galactose 4-epimerase. SLC35A2 transports UDP-galactose from the cytosol into Golgi. Four new host factors are shown: LAPTM4A (lysosomal-associated protein transmembrane 4 alpha) may be involved in the synthesis of Gb3 from LacCer; TM9SF2 (transmembrane 9 superfamily member 2) and TMEM165 (transmembrane protein 165) may play a role in maintaining a suitable environment in the Golgi for optimal glycosyltransferase activity; AHR (aryl hydrocarbon receptor) can directly bind and activate the promoter of the gene encoding serine palmityl transferase subunit A (SPTSSA), which regulates the first step in the biosynthesis of new sphingolipids.

LAPTM4A is ranked as a top hit in all four screens and has never been previously implicated as a host factor for Stx [64,113-115]. LAPTM4A knockout (KO) renders cells completely resistant to Stx1 and Stx2, but not other control toxins (ricin and cholera toxin). The resistance of LAPTM4A KO cells is at the same level as A4GALT KO cells. LAPTM4A is a poorly characterized small (233 amino acids) 4-transmembrane protein with unknown functions $[119,120]$. Tian et al. carried out mass-spectrometry-based lipidomic analysis and found that Gb3 is greatly reduced in LAPTM4A KO cells and the levels of Gb3 precursor LacCer are increased [64]. Yamaji et al. obtained similar results using thin-layer chromatography and radiography analysis [114]. These results demonstrate that LAPTM4A is essential for the last step of Gb3 biosynthesis.

LAPTM4A was initially reported to be localized on endosomes and lysosomes. However, the localization of LAPTM4A appears to be sensitive to a tag added to the N-terminus in these earlier studies [120-122]. Tian et al. found that LAPTM4A with a C-terminal tag was largely localized to Golgi in three different human cell lines [64]. The endogenous LAPTM4A has been detected in both the Golgi and lysosome fractions of rat liver membrane lysates $[119,120]$. These findings indicate that Golgi is at least one of the places 
containing LAPTM4A. Tian et al. also established the membrane topology of LAPTM4A, demonstrating that its $\mathrm{N}$ - and C-termini are both located in the cytosol, with two short luminal domains. Coimmunoprecipitation assays have shown that LAPTM4A can interact with A4GALT, but the expression level and Golgi-localization of A4GALT are not affected in LAPTM4A KO cells [64].

Both Tian et al. and Yamaji et al. showed that the requirement of LAPTM4A for Gb3 synthesis is not shared by its homolog LAPTM4B $[64,114]$. By constructing and evaluating a series of chimeric proteins between LAPTM4A and LAPTM4B, Tian et al. determined that the second luminal domain of LAPTM4A is required for its role in Gb3 synthesis. Based on these findings, Tian et al. proposed that LAPTM4A serves as a specific "activator" for A4GALT [64]. Supporting that suggestion, Yamaji et al. found that Gb3 synthesis activity in cell lysates of LAPTM4A KO cells is greatly reduced compared with control cell lysates. They also found that exogenously expressed A4GALT levels are not affected in LAPTM4A KO cells, although endogenous A4GALT levels in HeLa cells have been difficult to detect [114]. These findings clearly suggest that LAPTM4A is an essential cofactor for A4GALT [64,114]. Future studies are required to further elucidate whether LAPTM4A is required for A4GALT enzymatic activity and/or its stability. The molecular mechanism underlying LAPTM4A-A4GALT interactions also remains to be established.

In contrast with the specific requirement of LAPTM4A for Gb3 biosynthesis, TM9SF2 and TMEM165 are required for a broad range of glycosylation processes, including biosynthesis of gangliosides and heparan sulfate proteoglycan. They have been identified in a growing number of genetic screens for various toxins and viruses [123-127]. Mutations in TEME165 have been linked to congenital disorders of glycosylation in humans [128]. TMEM165 is a multitransmembrane protein, localized on Golgi, that has been proposed to act as an $\mathrm{Mn}^{2+}$ transporter to maintain $\mathrm{Mn}^{2+}$ homeostasis [129]. Since $\mathrm{Mn}^{2+}$ is an essential cofactor for many glycosyltransferases in Golgi, TMEM165 is required for the biosynthesis of both glycoproteins and glycolipids. Consistently, Tian et al. found that TMEM165 $\mathrm{KO}$ cells have low levels of not only Gb3 and Gb3 precursors but also gangliosides. The addition of $\mathrm{Mn}^{2+}$ to culture medium restored the binding of Stx to TMEM165 KO cells, which is consistent with the role of TMEM165 in regulating $\mathrm{Mn}^{2+}$ hemostasis $[64,128-130]$.

The function of TM9SF2 remains unknown. It contains nine transmembrane domains and belongs to a family of highly conserved membrane proteins, with four members in humans (TM9SF1 to TM9SF4). Yamaji et al. showed that Stx binding of TM9SF2-KO cells can be recovered by all TM9SF family members, suggesting that TM9SF2 family members regulate Gb3 synthesis by a conserved mechanism [114]. TM9SF2 was recently identified as a potential oncogene in colorectal cancer through transposon mutagenesis in mouse models and found to be overexpressed in many human colorectal cancer samples [131]. Although it was initially suggested to be an endosomal protein, recent studies using antibodies capable of recognizing endogenous TM9SF2 revealed that it is largely localized to the Golgi $[113,124]$. TM9SF2 KO cells showed a reduction in glycosylation of all glycolipids and glycoproteins, including heparan sulfate proteoglycan [124]. TM9SF2 KO cell lysates showed levels of A4GALT activity comparable with control lysates, further suggesting that TM9SF2 is not directly involved in A4GALT enzymatic activity in vitro [113,124,132]. The exact mechanism by which TM9SF2 affects glycosylation remains unknown and could be multifaceted. It is possible that TM9SF2 acts as a transporter for maintaining the hemostasis of some, as yet unidentified, elements critical for glycosylation, similar to TMEM165. It is also possible that TM9SF2 is involved in Gb3 biosynthesis by regulating retrograde trafficking of lipids and glycosyltransferases [64,114]. Tian et al. found that TM9SF2 KO cells appear to form large vacuoles in the cytosol and showed severely disrupted endosomal trafficking of exogenously loaded lipids [64]. This effect on endosomal trafficking has been shown for TM9SF2 paralogs in both Drosophila and yeast, suggesting that TM9SF2 plays a conserved role in this process $[133,134]$. As TM9SF2 is localized on the Golgi, the defects in endosomal trafficking could be secondary, although it remains possible that a low level of TM9SF2 is also localized on endosomes. 
The screen by Pacheco et al. is unique in that it was carried out using EHEC instead of purified Stx [113]. Besides Stx, EHEC also exhibits its virulence via a type III secretion system (T3SS), which injects a group of effectors into host cells to disrupt cell functions. The cell line used in the screen, HT-29, is not sensitive to purified Stx, but incubation with EHEC resulted in cell death via effectors injected through the T3SS. The screen was designed and carried out with the intention of identifying host factors required for T3SS virulence. Surprisingly, the top hits were all involved in the Gb3 biosynthesis pathway, suggesting that Gb3 is critical for the virulence of the T3SS, in addition to its role as the receptor for Stx, although the mechanism remains to be determined [113]. These findings further illustrated the importance of the Gb3 biosynthesis pathway as a therapeutic target for developing inhibitors against Stx and EHEC [64,113-115].

\section{Biomedical Application of Shiga Toxin Subunit A}

Protein toxins such as Stx are evolved to achieve both specific targeting of host cells and efficient delivery of a payload into the cytosol of target cells. These properties could be utilized for developing novel therapeutic proteins. Rapid progress has been made on utilizing Stx-A and Stx-B in recent years. Stx-A has been selected as a promising payload in constructing immunotoxins for targeting and killing cancer cells. Immunotoxins are fusion proteins composed of a toxic domain such as Stx-A and a targeting domain, which can be single-chain antibody fragments, nanobodies, or any other protein binders that can specifically recognize cell surface proteins expressed in cancer cells [135]. The concept of immunotoxins was proposed and explored in the 1970s [136], but this approach has encountered significant difficulties, including lack of specificity in targeting cancer cells, high systemic toxicity, and generation of neutralizing antibodies that render the immunotoxin ineffective. Fortunately, many of these challenges can now be addressed. For instance, highly specific cell surface proteins on myeloma cells have been validated, and specific antibodies against them developed [137]. Stx-A is an ideal payload for this purpose: (1) it is highly potent and targets $28 \mathrm{~S}$ rRNA - as a foreign protein, it would be difficult for cancer cells to develop resistance to Stx-A; (2) the population is not immunized against Stx; (3) it is relatively a small protein $(32 \mathrm{kDa})$, which facilitates protein engineering.

Exciting progress in utilizing Stx-A has been made by a biotech company, Molecular Template, which has been developing Stx-A-based immunotoxins (called engineered toxin bodies (ETBS)). Three generations of immunotoxins have been developed and tested. The first generation (MT-3724) was based on wild-type Stx2-A fusion with a single-chain variable fragment $(\mathrm{scFv})$ derived from an antibody targeting CD20, which is a B-cell surface antigen, targeted to treat B-cell lymphomas and leukemias (Figure 3A). This ETB is currently undergoing multiple Phase 2 studies to show monotherapy activity. The major side-effect is capillary leak syndrome, which is likely due to immune responses against ETB proteins [138-140].

The second-generation ETB utilized a modified Stx-A containing mutations to reduce immunogenicity (deimmunization, Figure 3A). A representative mutation, TAK-169, was created by the fusion of deimmunized Stx-A with an $\mathrm{scFv}$ targeting CD38, which is a marker for myeloma cells. Encouraging data on nonhuman primates have shown that TAK-169 can be dosed at higher levels than MT-3724 and can induce lower levels of immune response compared with MT-3724 [141,142]. In 2019, through a collaboration with Takeda Pharmaceutical, a Phase 1 first-in-human, multicenter, open-label study of TAK-169 began enrolling patients in an evaluation of safety, drug resistance, initial efficacy, pharmacokinetics (PK), and pharmacodynamics (PD) [142]. 
A

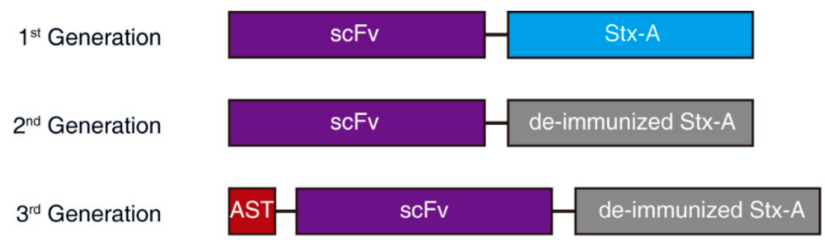

B



Figure 3. Schematic diagrams of engineering Stx-A and Stx-B for biomedical applications. (A) Three representative generations of engineered toxin bodies (ETBs) constructed with wild-type Stx-A (1st generation) or deimmunized Stx-A (2nd and 3rd generations). $\mathrm{scFv}$, single chain variable fragment; AST, antigen seeding technology (e.g., viral peptide is derived from cytomegalovirus). (B) STC (Shigalike toxin-based carrier) is a delivery system in which the Stx2 A1 piece is replaced with delivery cargoes like EGFP. Stx-B-TDP is a delivery system fusing Stx-B with the P. aeruginosa exotoxin A translocation domain (ETA-II) and cargoes, e.g., EGFP or N8A (an MDM2 inhibitor), at its C-terminus. Another design, e.g., the Stx-B-TDP-VHL-monobody, fuses ETA-II and cargoes (Von Hippel-Lindau (VHL) fusion with a monobody) at the C-terminus of Stx-B. An additional ER retention sequence (KDEL) is added for retrograde transport.

Another second-generation lead protein, MT-5111, incorporates a different scFv, targeting HER2. The binding site of MT-5111 to the HER2 domain is designed to be different from that of trastuzumab and pertuzumab, two commonly used antibodies against HER2positive tumors. In the presence of these monoclonal antibodies, MT-5111 can still bind to HER2 and induce effective cell killing. The Phase 1 clinical trial of MT-5111 is enrolling patients with HER2-positive solid tumors that have progressed after receiving other approved treatments $[143,144]$.

The third-generation ETB further includes the fusion of both a viral foreign peptide and deimmunized Stx-A to an ScFv targeting PD-L1 (Figure 3A). The viral peptide is derived from cytomegalovirus (CMV). Once delivered into target tumor cells, the viral peptide will be presented as a viral antigen and can activate CMV-reactive T-cells to recognize and destroy tumor cells. This technology is known as "antigen seeding"; this third-generation ETB is undergoing preclinical testing $[145,146]$.

\section{Biomedical Application of Shiga Toxin Subunit B}

Stx-B is an ideal tool for targeting Gb3-expressing cells. In healthy humans, Gb3 expression is highly restricted to only a few cell types, including dendritic cells [13]. As dendritic cells are primary antigen-presenting cells and play a critical role in inducing T-cell responses against viral pathogens and tumors, Stx-B has been explored to deliver antigens into dendritic cells for antigen presentation [147,148]. Haicheur and Benchetrit et al. discovered that Stx-B conjugated with ovalbumin (OVA), a full-size antigenic model protein, efficiently delivers exogenous peptides into the MHC class I- and class II-restricted delivery pathways of mouse dendritic cells. This pathway induces humoral and cellular immune responses without the use of adjuvants [149]. Choi et al. found that mice exposed to oral Stx1B conjugated with monkey rotavirus (SA-11) nonstructural protein NSP490 peptide were protected from rotavirus-mediated gastroenteritis attack. This is due to the strong Th1-mediated response, demonstrating that Stx-B-mediated delivery of viral antigens can elicit both humoral and cellular response in mice [150]. Vingert et al. showed that Stx-B 
can target dendritic cells in vivo and induce robust and sustained specific CD8+ T-cell responses [54,151].

Stx-B itself has also been utilized to develop vaccines against Stx and EHEC. In 2019, Kordbacheh et al. constructed the HcpA-EspA-Tir-Stx2-B (HETS) vector and immunized BALB/c mice with the purified protein [152]. Stx1-B and Stx2-B have also been fused to Brucella abortus lumazine synthase, a highly immunogenic and stable protein that serves as a scaffold to present foreign antigens. The chimeric proteins elicited strong humoral immune responses against different Stx variants in horses. NEAST (neutralizing equine anti-Shiga toxin) is produced using this chimeric antigen and has successfully passed preclinical and Phase I studies. Phase II/III clinical trials are ongoing in Argentina and are recruiting children with bloody diarrhea and Stx2 in feces [153].

Gb3 is also overexpressed in many human cancers [154-164]. Thus, Stx-B has been explored for targeting cancer cells for imaging tumor tissues. Viel and Dransart et al. injected fluorophore-labeled Stx-B intravenously into nude mice xenografted with GFP-expressing HT29 cells and studied its distribution. Stx-B accumulated in HT29 tumor xenografts with high Gb3 expression. In addition, fluorescent Stx-B was found to be slowly cleared through renal excretion. Immunofluorescence staining of the tumor section confirmed that Stx-B not only accumulated in Gb3-positive tumor cells but also entered the epithelial cells of Gb3-expressing neovascularization as well as monocytes and macrophages around the transplanted tumor tissues [54]. Stimmer et al. detected Gb3 expression in primary and metastatic breast cancer cytological specimens as well as human breast cancer xenografts (HBCxs) using Stx-B-CY3 conjugate [156].

Another study by Couture et al. (2011) demonstrated that Stx-B-containing microvesicles can be used to label tumor cells expressing Gb3, which generates hyperechoic signals in ultrasound imaging, and for molecular tumor imaging and to guide ultrasound treatment [165]. For example, Stx-B microvesicles can be used to carry out contrast-enhanced ultrasound imaging of bladder cancer cells that express Gb3 [158,166]. Contrast-enhanced ultrasound technology is already used widely by clinical radiologists, with the advantage of avoiding ionizing radiation [167].

As the direct use of Stx for cancer therapy likely produces high toxicity, several strategies have been developed to utilize Stx-B for the delivery of alternative cytotoxic payloads. The first strategy is to use Stx-B to deliver drugs that are less potent than Stx-A, thus reducing side-effects. For instance, Tarrago-Trani et al. used Stx-B to deliver the photosensitizer e6 chloride (Ce6) to Gb3-positive Vero cells. Ce6 is a second-generation photosensitizer with antitumor activity when used in conjunction with irradiation. Compared with free Ce6, Ce6-Stx-B has been proven to be more effective in delivering Ce6 into target cells [168]. In 2007, Alaoui et al. designed a prodrug Stx-B-SH by conjugating camptothecin SN-38, a camptocamptoid compound that inhibits topoisomerase I. When delivered to Gb3-positive HT-29 colorectal cancer cells and HeLa cells, this compound induces the death of the target cells [169]. A year later, the same group linked RO5-4864, a ligand with high affinity to mitochondrial peripheral benzodiazepine receptors (mPBRs), to Stx-B through a cleavable linker arm. The precursor drug is cleaved intracellularly to release the active ingredient, which improved the cytotoxic activity and antitumor specificity of RO5-4864 in cultured cancer cells [170].

In 2015, Batisse et al. combined Stx-B with a potent auristatin derivative (monomethyl auristatin (MMA)) and optimized the drug conjugation, demonstrating that this targeting system can contribute to selective elimination of Gb3-positive cancer cells in vitro [171]. The same year, Kostova et al. synthesized Stx-B-doxorubicin (StxB-Doxo) and Stx-Bmonomethyl auristatin $\mathrm{F}$ (StxB-MMAF), two cytotoxic conjugates with strong tumorsuppressive activity in the nanomolar range against HT29 cells [172].

The second strategy is to use protein/peptide cargo targeting cytosolic signaling pathways to replace the highly toxic Stx-A. This can be achieved by fusion of a cargo protein directly to a modified and detoxified Stx-A and then using Stx-B for targeting and delivery into Gb3-positive cells. In 2015, Ryou et al. designed the Shiga-like toxin-based 
carrier (STC), a delivery system containing Stx-B as the receptor-binding domain and the nontoxic Stx2A ${ }^{190-297}$ as a carrier directly fused with the protein cargo (Figure 3B) [173].

Inspired by the fact that the Pseudomonas aeruginosa exotoxin A (PE) translocation domain (the mature form of residues 252 to 364) can be genetically fused to a variety of substances (including proteins, enzymes, and peptides) and efficiently transport them into the cytosol [174], Ryou et al. further improved their STC system by fusing Stx-B to the $\mathrm{N}$-terminus of the Pseudomonas aeruginosa exotoxin A (ETA-II, TDP) translocation domain; the $\mathrm{C}$-terminus of TDP was fused to the protein cargo to be delivered. The ER retention sequence (KDEL) was fused to the C-terminus of the cargo for retrograde transport. TDP plays a role in the retrograde transport of the cargo from the ER to the cytosol, and, without TDP, the cargo cannot be released into the cytosol. The authors utilized this system and successfully delivered N8A peptide, which is a mouse double minute 2 (MDM2) inhibitor that blocks the degradation of p53 in cells. The author showed that injection of Stx-B-TDPN8A suppressed tumor growth in vivo in xenograft mouse models without significant side-effects [175]. The same delivery system has been shown to deliver PEA-15, an ERK kinase regulator, into cells. Nonphosphorylated PEA-15 directly binds to ERK2 and blocks its function, and by cytosolic delivery of PEA-15 mutants with different phosphorylation sites, as well as affinity to ERK2 via the Stx2B-ETAII chimera, the high-affinity mutant was found to have a strong inhibitory effect on cell proliferation by blocking intracellular ERK2 functions [176].

In 2019, Schmit and Neopane et al. further improved the delivery system by linking Stx2B-ETAII with the Von Hippel-Lindau (VHL)-monobody fusion protein. This system targets cancer cells, with the aim of degrading the endogenous tyrosine kinase Lck in Jurkat T-cells and enhancing the inhibition of T-cell receptor (TCR) signaling [177]. VHL is the substrate receptor of the Cullin 2 E3 ligase complex. It can recruit the E3 ligase complex and induce the ubiquitination and degradation of the fusion protein. The monobody in this delivery system can be replaced with any substance that binds an intracellular protein of interest (POI). In combination with VHL, an intracellular POI can be targeted for degradation [177].

Systemic immunogenicity from the toxin protein is one possible limitation to the widespread application of the Stx-B-based delivery system. Possible solutions to this inherent problem include the removal of immunogenic epitopes by protein engineering, encapsulation of the protein [178], and reduction of protein accumulation by local application (e.g., intratumoral injection) [177].

\section{Conclusions}

The E. coli outbreak in Germany in 2011, which caused HUS in over 800 patients and 54 deaths, was produced by a new strain, O104:H4 [179]. This strain belongs to enteroaggregative E. coli instead of the usual EHEC strains but acquired virulence by acquiring an Stx2 gene, illustrating the continual threat of Stx in causing major outbreaks and the need for developing effective countermeasures. Recent progress in uncovering host factors and establishing a molecular understanding of the biosynthesis of $\mathrm{Gb} 3$ has provided new targets for developing inhibitors that can protect cells from Stx. The physiological function and tissue distribution of Gb3 in humans remain a key open question. Recent studies have also begun to reveal the potential role of Stx in taming immune responses and established human intestinal organoid models for understanding how Stx actions may benefit the bacteria. The observation that EHEC T3SS also requires Gb3 is intriguing and deserves further exploration. Excitingly, Stx-based therapeutic protein has entered clinical trials, which will pave the way for broader biomedical applications of toxin-based therapeutics and tools.

Author Contributions: Conceptualization, Y.L. and M.D.; writing—original draft preparation, Y.L.; writing - review and editing, S.T., H.T., and M.D.; creation of figures: S.T. and Y.L.; supervision, S.T. and M.D.; All authors have read and agreed to the published version of the manuscript. 
Funding: This research was funded by the Borroughs Wellcome Fund (M.D. holds the Investigator in the Pathogenesis of Infectious Disease award), the American Urologic Association/Urology Care Foundation, and the Society of Urodynamics, Female Pelvic Medicine and Urogenital Reconstruction (to H.T.). The APC was funded by the Borroughs Wellcome Fund.

Institutional Review Board Statement: Not applicable.

Informed Consent Statement: Not applicable.

Data Availability Statement: Data sharing not applicable. No new data were created or analyzed in this study. Data sharing is not applicable to this article.

Acknowledgments: We thank Xiaozhe Xiong for his help with the figures. Owing to the narrow focus of this review, discussion and citation of much significant and historical work had to be excluded. We apologize for those omissions and refer readers to many recent comprehensive and in-depth reviews on related topics.

Conflicts of Interest: The authors declare no conflict of interest.

\section{References}

1. Trofa, A.F.; Ueno-Olsen, H.; Oiwa, R.; Yoshikawa, M. Dr. Kiyoshi Shiga: Discoverer of the dysentery bacillus. Clin. Infect. Dis. 1999, 29, 1303-1306. [CrossRef] [PubMed]

2. Zaidi, M.B.; Estrada-Garcia, T. Shigella: A Highly Virulent and Elusive Pathogen. Curr. Trop. Med. Rep. 2014, 1, 81-87. [CrossRef] [PubMed]

3. Konowalchuk, J.; Speirs, J.I.; Stavric, S. Vero response to a cytotoxin of Escherichia coli. Infect. Immun. 1977, 18, 775-779. [CrossRef]

4. O'Brien, A.D.; Newland, J.W.; Miller, S.F.; Holmes, R.K.; Smith, H.W.; Formal, S.B. Shiga-like toxin-converting phages from Escherichia coli strains that cause hemorrhagic colitis or infantile diarrhea. Science 1984, 226, 694-696. [CrossRef]

5. Jackson, M.P.; Neill, R.J.; O’Brien, A.D.; Holmes, R.K.; Newland, J.W. Nucleotide sequence analysis and comparison of the structural genes for Shiga-like toxin I and Shiga-like toxin II encoded by bacteriophages from Escherichia coli 933. FEMS Microbiol. Lett. 1987, 44, 109-114. [CrossRef]

6. Centers for Disease Control and Prevention (CDC). National Shiga Toxin-Producing Escherichia coli (STEC) Surveillance Overview. Atlanta, Georgia: US Department of Health and Human Services, CDC. 2012. Available online: https://www.cdc.gov/ nationalsurveillance/ecoli-surveillance/html (accessed on 17 March 2021).

7. Tarr, P.I.; Gordon, C.A.; Chandler, W.L. Shiga-toxin-producing Escherichia coli and haemolytic uraemic syndrome. Lancet 2005, 365, 1073-1086. [CrossRef]

8. Boyce, T.G.; Swerdlow, D.L.; Griffin, P.M. Escherichia coli O157:H7 and the hemolytic-uremic syndrome. N. Engl. J. Med. 1995, 333, 364-368. [CrossRef]

9. Joseph, A.; Cointe, A.; Mariani Kurkdjian, P.; Rafat, C.; Hertig, A. Shiga Toxin-Associated Hemolytic Uremic Syndrome: A Narrative Review. Toxins 2020, 12, 67. [CrossRef]

10. Williams, D.M.; Sreedhar, S.S.; Mickell, J.J.; Chan, J.C. Acute kidney failure: A pediatric experience over 20 years. Arch. Pediatr. Adolesc. Med. 2002, 156, 893-900. [CrossRef]

11. Johannes, L.; Romer, W. Shiga toxins-from cell biology to biomedical applications. Nat. Rev. Microbiol. 2010, 8, 105-116. [CrossRef]

12. Obrig, T.G. Escherichia coli Shiga Toxin Mechanisms of Action in Renal Disease. Toxins 2010, 2, 2769-2794. [CrossRef] [PubMed]

13. Engedal, N.; Skotland, T.; Torgersen, M.L.; Sandvig, K. Shiga toxin and its use in targeted cancer therapy and imaging. Microb. Biotechnol. 2011, 4, 32-46. [CrossRef]

14. Bergan, J.; Dyve Lingelem, A.B.; Simm, R.; Skotland, T.; Sandvig, K. Shiga toxins. Toxicon 2012, 60, 1085-1107. [CrossRef]

15. Obrig, T.G.; Karpman, D. Shiga toxin pathogenesis: Kidney complications and renal failure. Curr. Top. Microbiol. Immunol. 2012, 357, 105-136. [CrossRef] [PubMed]

16. Pacheco, A.R.; Sperandio, V. Shiga toxin in enterohemorrhagic E.coli: Regulation and novel anti-virulence strategies. Front. Cell Infect. Microbiol. 2012, 2, 81. [CrossRef] [PubMed]

17. Melton-Celsa, A.R. Shiga Toxin (Stx) Classification, Structure, and Function. Microbiol. Spectr. 2014, 2, 37-53. [CrossRef] [PubMed]

18. Jeong, Y.J.; Park, S.K.; Yoon, S.J.; Park, Y.J.; Lee, M.S. Experimental In Vivo Models of Bacterial Shiga Toxin-Associated Hemolytic Uremic Syndrome. J. Microbiol. Biotechnol. 2018, 28, 1413-1425. [CrossRef] [PubMed]

19. Lee, M.S.; Tesh, V.L. Roles of Shiga Toxins in Immunopathology. Toxins 2019, 11, 212. [CrossRef]

20. Lingwood, C. Verotoxin Receptor-Based Pathology and Therapies. Front. Cell Infect. Microbiol. 2020, 10, 123. [CrossRef]

21. Luginbuehl, V.; Meier, N.; Kovar, K.; Rohrer, J. Intracellular drug delivery: Potential usefulness of engineered Shiga toxin subunit B for targeted cancer therapy. Biotechnol. Adv. 2018, 36, 613-623. [CrossRef]

22. Menge, C. Molecular Biology of Escherichia Coli Shiga Toxins' Effects on Mammalian Cells. Toxins 2020, 12, 345. [CrossRef]

23. Fraser, M.E.; Chernaia, M.M.; Kozlov, Y.V.; James, M.N. Crystal structure of the holotoxin from Shigella dysenteriae at 2.5 A resolution. Nat. Struct. Biol. 1994, 1, 59-64. [CrossRef] [PubMed] 
24. Stein, P.E.; Boodhoo, A.; Tyrrell, G.J.; Brunton, J.L.; Read, R.J. Crystal structure of the cell-binding B oligomer of verotoxin-1 from E. coli. Nature 1992, 355, 748-750. [CrossRef] [PubMed]

25. Endo, Y.; Tsurugi, K.; Yutsudo, T.; Takeda, Y.; Ogasawara, T.; Igarashi, K. Site of action of a Vero toxin (VT2) from Escherichia coli O157:H7 and of Shiga toxin on eukaryotic ribosomes. RNA N-glycosidase activity of the toxins. Eur. J. Biochem. 1988, 171, 45-50. [CrossRef]

26. Saxena, S.K.; O’Brien, A.D.; Ackerman, E.J. Shiga toxin, Shiga-like toxin II variant, and ricin are all single-site RNA N-glycosidases of 28 S RNA when microinjected into Xenopus oocytes. J. Biol. Chem. 1989, 264, 596-601. [CrossRef]

27. Ogasawara, T.; Ito, K.; Igarashi, K.; Yutsudo, T.; Nakabayashi, N.; Takeda, Y. Inhibition of protein synthesis by a Vero toxin (VT2 or Shiga-like toxin II) produced by Escherichia coli O157:H7 at the level of elongation factor 1-dependent aminoacyl-tRNA binding to ribosomes. Microb. Pathog. 1988, 4, 127-135. [CrossRef]

28. Lindberg, A.A.; Brown, J.E.; Stromberg, N.; Westling-Ryd, M.; Schultz, J.E.; Karlsson, K.A. Identification of the carbohydrate receptor for Shiga toxin produced by Shigella dysenteriae type 1. J. Biol. Chem. 1987, 262, 1779-1785. [CrossRef]

29. Ling, H.; Boodhoo, A.; Hazes, B.; Cummings, M.D.; Armstrong, G.D.; Brunton, J.L.; Read, R.J. Structure of the shiga-like toxin I B-pentamer complexed with an analogue of its receptor Gb3. Biochemistry 1998, 37, 1777-1788. [CrossRef]

30. Romer, W.; Pontani, L.L.; Sorre, B.; Rentero, C.; Berland, L.; Chambon, V.; Lamaze, C.; Bassereau, P.; Sykes, C.; Gaus, K.; et al. Actin dynamics drive membrane reorganization and scission in clathrin-independent endocytosis. Cell 2010, 140, 540-553. [CrossRef]

31. Sandvig, K.; van Deurs, B. Endocytosis, intracellular transport, and cytotoxic action of Shiga toxin and ricin. Physiol. Rev. 1996, 76, 949-966. [CrossRef]

32. Sandvig, K.; Olsnes, S.; Brown, J.E.; Petersen, O.W.; van Deurs, B. Endocytosis from coated pits of Shiga toxin: A glycolipid-binding protein from Shigella dysenteriae 1. J. Cell Biol. 1989, 108, 1331-1343. [CrossRef]

33. Saint-Pol, A.; Yelamos, B.; Amessou, M.; Mills, I.G.; Dugast, M.; Tenza, D.; Schu, P.; Antony, C.; McMahon, H.T.; Lamaze, C.; et al. Clathrin adaptor epsinR is required for retrograde sorting on early endosomal membranes. Dev. Cell 2004, 6, 525-538. [CrossRef]

34. Johannes, L.; Popoff, V. Tracing the retrograde route in protein trafficking. Cell 2008, 135, 1175-1187. [CrossRef]

35. Sandvig, K.; Skotland, T.; van Deurs, B.; Klokk, T.I. Retrograde transport of protein toxins through the Golgi apparatus. Histochem. Cell Biol. 2013, 140, 317-326. [CrossRef] [PubMed]

36. Mallard, F.; Antony, C.; Tenza, D.; Salamero, J.; Goud, B.; Johannes, L. Direct pathway from early/recycling endosomes to the Golgi apparatus revealed through the study of shiga toxin B-fragment transport. J. Cell Biol. 1998, 143, 973-990. [CrossRef]

37. Garred, O.; Dubinina, E.; Polesskaya, A.; Olsnes, S.; Kozlov, J.; Sandvig, K. Role of the disulfide bond in Shiga toxin A-chain for toxin entry into cells. J. Biol. Chem. 1997, 272, 11414-11419. [CrossRef] [PubMed]

38. Fagerquist, C.K.; Sultan, O. Top-down proteomic identification of furin-cleaved alpha-subunit of Shiga toxin 2 from Escherichia coli O157:H7 using MALDI-TOF-TOF-MS/MS. J. Biomed. Biotechnol. 2010, 2010, 123460. [CrossRef] [PubMed]

39. Scheutz, F.; Teel, L.D.; Beutin, L.; Pierard, D.; Buvens, G.; Karch, H.; Mellmann, A.; Caprioli, A.; Tozzoli, R.; Morabito, S.; et al. Multicenter evaluation of a sequence-based protocol for subtyping Shiga toxins and standardizing Stx nomenclature. J. Clin. Microbiol. 2012, 50, 2951-2963. [CrossRef] [PubMed]

40. Bai, X.; Fu, S.; Zhang, J.; Fan, R.; Xu, Y.; Sun, H.; He, X.; Xu, J.; Xiong, Y. Identification and pathogenomic analysis of an Escherichia coli strain producing a novel Shiga toxin 2 subtype. Sci. Rep. 2018, 8, 6756. [CrossRef] [PubMed]

41. Hughes, A.C.; Zhang, Y.; Bai, X.; Xiong, Y.; Wang, Y.; Yang, X.; Xu, Q.; He, X. Structural and Functional Characterization of Stx2k, a New Subtype of Shiga Toxin 2. Microorganisms 2019, 8, 4. [CrossRef] [PubMed]

42. Yang, X.; Bai, X.; Zhang, J.; Sun, H.; Fu, S.; Fan, R.; He, X.; Scheutz, F.; Matussek, A.; Xiong, Y. Escherichia coli strains producing a novel Shiga toxin 2 subtype circulate in China. Int. J. Med. Microbiol. 2020, 310, 151377. [CrossRef] [PubMed]

43. Fuller, C.A.; Pellino, C.A.; Flagler, M.J.; Strasser, J.E.; Weiss, A.A. Shiga toxin subtypes display dramatic differences in potency. Infect. Immun. 2011, 79, 1329-1337. [CrossRef]

44. Luna-Gierke, R.E.; Griffin, P.M.; Gould, L.H.; Herman, K.; Bopp, C.A.; Strockbine, N.; Mody, R.K. Outbreaks of non-O157 Shiga toxin-producing Escherichia coli infection: USA. Epidemiol. Infect. 2014, 142, 2270-2280. [CrossRef]

45. Fraser, M.E.; Fujinaga, M.; Cherney, M.M.; Melton-Celsa, A.R.; Twiddy, E.M.; O’Brien, A.D.; James, M.N. Structure of shiga toxin type 2 (Stx2) from Escherichia coli O157:H7. J. Biol. Chem. 2004, 279, 27511-27517. [CrossRef] [PubMed]

46. Casanova, N.A.; Redondo, L.M.; Dailoff, G.C.; Arenas, D.; Fernandez Miyakawa, M.E. Overview of the role of Shiga toxins in porcine edema disease pathogenesis. Toxicon 2018, 148, 149-154. [CrossRef]

47. Farooq, S.; Hussain, I.; Mir, M.A.; Bhat, M.A.; Wani, S.A. Isolation of atypical enteropathogenic Escherichia coli and Shiga toxin 1 and 2f-producing Escherichia coli from avian species in India. Lett. Appl. Microbiol. 2009, 48, 692-697. [CrossRef] [PubMed]

48. Murakami, K.; Etoh, Y.; Ichihara, S.; Maeda, E.; Takenaka, S.; Horikawa, K.; Narimatsu, H.; Kawano, K.; Kawamura, Y.; Ito, K. Isolation and characteristics of Shiga toxin 2f-producing Escherichia coli among pigeons in Kyushu, Japan. PLoS ONE 2014, 9, e86076. [CrossRef]

49. Schmidt, H.; Scheef, J.; Morabito, S.; Caprioli, A.; Wieler, L.H.; Karch, H. A new Shiga toxin 2 variant (Stx2f) from Escherichia coli isolated from pigeons. Appl. Environ. Microbiol. 2000, 66, 1205-1208. [CrossRef] [PubMed]

50. Lacher, D.W.; Gangiredla, J.; Patel, I.; Elkins, C.A.; Feng, P.C. Use of the Escherichia coli Identification Microarray for Characterizing the Health Risks of Shiga Toxin-Producing Escherichia coli Isolated from Foods. J. Food Prot. 2016, 79, 1656-1662. [CrossRef] [PubMed] 
51. Tyrrell, G.J.; Ramotar, K.; Toye, B.; Boyd, B.; Lingwood, C.A.; Brunton, J.L. Alteration of the carbohydrate binding specificity of verotoxins from Gal alpha 1-4Gal to GalNAc beta 1-3Gal alpha 1-4Gal and vice versa by site-directed mutagenesis of the binding subunit. Proc. Natl. Acad. Sci. USA 1992, 89, 524-528. [CrossRef]

52. Nakajima, H.; Kiyokawa, N.; Katagiri, Y.U.; Taguchi, T.; Suzuki, T.; Sekino, T.; Mimori, K.; Ebata, T.; Saito, M.; Nakao, H.; et al. Kinetic analysis of binding between Shiga toxin and receptor glycolipid Gb3Cer by surface plasmon resonance. J. Biol. Chem. 2001, 276, 42915-42922. [CrossRef] [PubMed]

53. Friedrich, A.W.; Bielaszewska, M.; Zhang, W.L.; Pulz, M.; Kuczius, T.; Ammon, A.; Karch, H. Escherichia coli harboring Shiga toxin 2 gene variants: Frequency and association with clinical symptoms. J. Infect. Dis. 2002, 185, 74-84. [CrossRef]

54. Viel, T.; Dransart, E.; Nemati, F.; Henry, E.; Thézé, B.; Decaudin, D.; Lewandowski, D.; Boisgard, R.; Johannes, L.; Tavitian, B. In Vivo Tumor Targeting by the B-Subunit of Shiga Toxin. Mol. Imaging 2008, 7, 239-247. [CrossRef]

55. Kouzel, I.U.; Pohlentz, G.; Schmitz, J.S.; Steil, D.; Humpf, H.U.; Karch, H.; Muthing, J. Shiga Toxin Glycosphingolipid Receptors in Human Caco-2 and HCT-8 Colon Epithelial Cell Lines. Toxins 2017, 9, 338. [CrossRef]

56. Amaral, M.M.; Sacerdoti, F.; Jancic, C.; Repetto, H.A.; Paton, A.W.; Paton, J.C.; Ibarra, C. Action of shiga toxin type-2 and subtilase cytotoxin on human microvascular endothelial cells. PLoS ONE 2013, 8, e70431. [CrossRef] [PubMed]

57. Ehrlenbach, S.; Rosales, A.; Posch, W.; Wilflingseder, D.; Hermann, M.; Brockmeyer, J.; Karch, H.; Satchell, S.C.; Wurzner, R.; Orth-Holler, D. Shiga toxin 2 reduces complement inhibitor CD59 expression on human renal tubular epithelial and glomerular endothelial cells. Infect. Immun. 2013, 81, 2678-2685. [CrossRef] [PubMed]

58. Matussek, A.; Lauber, J.; Bergau, A.; Hansen, W.; Rohde, M.; Dittmar, K.E.; Gunzer, M.; Mengel, M.; Gatzlaff, P.; Hartmann, M.; et al. Molecular and functional analysis of Shiga toxin-induced response patterns in human vascular endothelial cells. Blood 2003, 102, 1323-1332. [CrossRef]

59. Mukhopadhyay, S.; Linstedt, A.D. Manganese blocks intracellular trafficking of Shiga toxin and protects against Shiga toxicosis. Science 2012, 335, 332-335. [CrossRef]

60. Taga, S.; Carlier, K.; Mishal, Z.; Capoulade, C.; Mangeney, M.; Lecluse, Y.; Coulaud, D.; Tetaud, C.; Pritchard, L.L.; Tursz, T.; et al. Intracellular signaling events in CD77-mediated apoptosis of Burkitt's lymphoma cells. Blood 1997, 90, 2757-2767. [CrossRef]

61. Brandelli, J.R.; Griener, T.P.; Laing, A.; Mulvey, G.; Armstrong, G.D. The Effects of Shiga Toxin 1, 2 and Their Subunits on Cytokine and Chemokine Expression by Human Macrophage-Like THP-1 Cells. Toxins 2015, 7, 4054-4066. [CrossRef]

62. Johansson, K.; Willysson, A.; Kristoffersson, A.C.; Tontanahal, A.; Gillet, D.; Stahl, A.L.; Karpman, D. Shiga Toxin-Bearing Microvesicles Exert a Cytotoxic Effect on Recipient Cells Only When the Cells Express the Toxin Receptor. Front. Cell Infect. Microbiol. 2020, 10, 212. [CrossRef]

63. Waddell, T.; Cohen, A.; Lingwood, C.A. Induction of verotoxin sensitivity in receptor-deficient cell lines using the receptor glycolipid globotriosylceramide. Proc. Natl. Acad. Sci. USA 1990, 87, 7898-7901. [CrossRef]

64. Tian, S.; Muneeruddin, K.; Choi, M.Y.; Tao, L.; Bhuiyan, R.H.; Ohmi, Y.; Furukawa, K.; Furukawa, K.; Boland, S.; Shaffer, S.A.; et al. Genome-wide CRISPR screens for Shiga toxins and ricin reveal Golgi proteins critical for glycosylation. PLoS Biol. 2018, 16, e2006951. [CrossRef]

65. Lingwood, C.A.; Binnington, B.; Manis, A.; Branch, D.R. Globotriaosyl ceramide receptor function-Where membrane structure and pathology intersect. FEBS Lett. 2010, 584, 1879-1886. [CrossRef]

66. Lingwood, C.A.; Manis, A.; Mahfoud, R.; Khan, F.; Binnington, B.; Mylvaganam, M. New aspects of the regulation of glycosphingolipid receptor function. Chem. Phys. Lipids 2010, 163, 27-35. [CrossRef] [PubMed]

67. Obrig, T.G.; Louise, C.B.; Lingwood, C.A.; Boyd, B.; Barley-Maloney, L.; Daniel, T.O. Endothelial heterogeneity in Shiga toxin receptors and responses. J. Biol. Chem. 1993, 268, 15484-15488. [CrossRef]

68. Kouzel, I.U.; Kehl, A.; Berger, P.; Liashkovich, I.; Steil, D.; Makalowski, W.; Suzuki, Y.; Pohlentz, G.; Karch, H.; Mellmann, A.; et al. RAB5A and TRAPPC6B are novel targets for Shiga toxin 2a inactivation in kidney epithelial cells. Sci. Rep. 2020, 10, 4945. [CrossRef] [PubMed]

69. Watson, C.L.; Mahe, M.M.; Munera, J.; Howell, J.C.; Sundaram, N.; Poling, H.M.; Schweitzer, J.I.; Vallance, J.E.; Mayhew, C.N.; Sun, Y.; et al. An in vivo model of human small intestine using pluripotent stem cells. Nat. Med. 2014, 20, 1310-1314. [CrossRef] [PubMed]

70. Karve, S.S.; Pradhan, S.; Ward, D.V.; Weiss, A.A. Intestinal organoids model human responses to infection by commensal and Shiga toxin producing Escherichia coli. PLoS ONE 2017, 12, e0178966. [CrossRef]

71. Pradhan, S.; Karve, S.S.; Weiss, A.A.; Hawkins, J.; Poling, H.M.; Helmrath, M.A.; Wells, J.M.; McCauley, H.A. Tissue Responses to Shiga Toxin in Human Intestinal Organoids. Cell Mol. Gastroenterol. Hepatol. 2020, 10, 171-190. [CrossRef]

72. Mohawk, K.L.; O’Brien, A.D. Mouse models of Escherichia coli O157:H7 infection and shiga toxin injection. J. Biomed. Biotechnol. 2011, 2011, 258185. [CrossRef]

73. Okuda, T.; Tokuda, N.; Numata, S.; Ito, M.; Ohta, M.; Kawamura, K.; Wiels, J.; Urano, T.; Tajima, O.; Furukawa, K.; et al. Targeted disruption of Gb3/CD77 synthase gene resulted in the complete deletion of globo-series glycosphingolipids and loss of sensitivity to verotoxins. J. Biol. Chem. 2006, 281, 10230-10235. [CrossRef] [PubMed]

74. Paixao-Cavalcante, D.; Botto, M.; Cook, H.T.; Pickering, M.C. Shiga toxin-2 results in renal tubular injury but not thrombotic microangiopathy in heterozygous factor H-deficient mice. Clin. Exp. Immunol. 2009, 155, 339-347. [CrossRef] [PubMed]

75. Keepers, T.R.; Psotka, M.A.; Gross, L.K.; Obrig, T.G. A murine model of HUS: Shiga toxin with lipopolysaccharide mimics the renal damage and physiologic response of human disease. J. Am. Soc. Nephrol. 2006, 17, 3404-3414. [CrossRef] [PubMed] 
76. Lee, M.S.; Kwon, H.; Lee, E.Y.; Kim, D.J.; Park, J.H.; Tesh, V.L.; Oh, T.K.; Kim, M.H. Shiga Toxins Activate the NLRP3 Inflammasome Pathway To Promote Both Production of the Proinflammatory Cytokine Interleukin-1beta and Apoptotic Cell Death. Infect. Immun. 2016, 84, 172-186. [CrossRef]

77. Havira, M.S.; Ta, A.; Kumari, P.; Wang, C.; Russo, A.J.; Ruan, J.; Rathinam, V.A.; Vanaja, S.K. Shiga toxin suppresses noncanonical inflammasome responses to cytosolic LPS. Sci. Immunol. 2020, 5, eabc0217. [CrossRef]

78. Wadolkowski, E.A.; Burris, J.A.; O’Brien, A.D. Mouse model for colonization and disease caused by enterohemorrhagic Escherichia coli O157:H7. Infect. Immun. 1990, 58, 2438-2445. [CrossRef]

79. Lindgren, S.W.; Melton, A.R.; O’Brien, A.D. Virulence of enterohemorrhagic Escherichia coli O91:H21 clinical isolates in an orally infected mouse model. Infect. Immun. 1993, 61, 3832-3842. [CrossRef] [PubMed]

80. Shimizu, K.; Asahara, T.; Nomoto, K.; Tanaka, R.; Hamabata, T.; Ozawa, A.; Takeda, Y. Development of a lethal Shiga toxinproducing Escherichia coli-infection mouse model using multiple mitomycin C treatment. Microb. Pathog. 2003, 35, 1-9. [CrossRef]

81. Eaton, K.A.; Friedman, D.I.; Francis, G.J.; Tyler, J.S.; Young, V.B.; Haeger, J.; Abu-Ali, G.; Whittam, T.S. Pathogenesis of renal disease due to enterohemorrhagic Escherichia coli in germ-free mice. Infect. Immun. 2008, 76, 3054-3063. [CrossRef]

82. Mallick, E.M.; McBee, M.E.; Vanguri, V.K.; Melton-Celsa, A.R.; Schlieper, K.; Karalius, B.J.; O’Brien, A.D.; Butterton, J.R.; Leong, J.M.; Schauer, D.B. A novel murine infection model for Shiga toxin-producing Escherichia coli. J. Clin. Investig. 2012, 122, $4012-4024$. [CrossRef]

83. Sugatani, J.; Komiyama, N.; Mochizuki, T.; Hoshino, M.; Miyamoto, D.; Igarashi, T.; Hoshi, S.; Miwa, M. Urinary concentrating defect in rats given Shiga toxin: Elevation in urinary AQP2 level associated with polyuria. Life Sci. 2002, 71, 171-189. [CrossRef]

84. Zotta, E.; Lago, N.; Ochoa, F.; Repetto, H.A.; Ibarra, C. Development of an experimental hemolytic uremic syndrome in rats. Pediatr. Nephrol. 2008, 23, 559-567. [CrossRef]

85. Silberstein, C.; Lucero, M.S.; Zotta, E.; Copeland, D.P.; Lingyun, L.; Repetto, H.A.; Ibarra, C. A glucosylceramide synthase inhibitor protects rats against the cytotoxic effects of shiga toxin 2. Pediatr. Res. 2011, 69, 390-394. [CrossRef] [PubMed]

86. Stone, S.M.; Thorpe, C.M.; Ahluwalia, A.; Rogers, A.B.; Obata, F.; Vozenilek, A.; Kolling, G.L.; Kane, A.V.; Magun, B.E.; Jandhyala, D.M. Shiga toxin 2-induced intestinal pathology in infant rabbits is A-subunit dependent and responsive to the tyrosine kinase and potential ZAK inhibitor imatinib. Front. Cell Infect. Microbiol. 2012, 2, 135. [CrossRef]

87. Garcia, A.; Bosques, C.J.; Wishnok, J.S.; Feng, Y.; Karalius, B.J.; Butterton, J.R.; Schauer, D.B.; Rogers, A.B.; Fox, J.G. Renal injury is a consistent finding in Dutch Belted rabbits experimentally infected with enterohemorrhagic Escherichia coli. J. Infect. Dis. 2006, 193, 1125-1134. [CrossRef]

88. Garcia, A.; Marini, R.P.; Catalfamo, J.L.; Knox, K.A.; Schauer, D.B.; Rogers, A.B.; Fox, J.G. Intravenous Shiga toxin 2 promotes enteritis and renal injury characterized by polymorphonuclear leukocyte infiltration and thrombosis in Dutch Belted rabbits. Microbes Infect. 2008, 10, 650-656. [CrossRef] [PubMed]

89. Kang, G.; Pulimood, A.B.; Koshi, R.; Hull, A.; Acheson, D.; Rajan, P.; Keusch, G.T.; Mathan, V.I.; Mathan, M.M. A monkey model for enterohemorrhagic Escherichia coli infection. J. Infect. Dis. 2001, 184, 206-210. [CrossRef] [PubMed]

90. Siegler, R.L.; Pysher, T.J.; Tesh, V.L.; Taylor, F.B., Jr. Response to single and divided doses of Shiga toxin-1 in a primate model of hemolytic uremic syndrome. J. Am. Soc. Nephrol. 2001, 12, 1458-1467.

91. Siegler, R.L.; Obrig, T.G.; Pysher, T.J.; Tesh, V.L.; Denkers, N.D.; Taylor, F.B. Response to Shiga toxin 1 and 2 in a baboon model of hemolytic uremic syndrome. Pediatr. Nephrol. 2003, 18, 92-96. [CrossRef]

92. Stearns-Kurosawa, D.J.; Oh, S.Y.; Cherla, R.P.; Lee, M.S.; Tesh, V.L.; Papin, J.; Henderson, J.; Kurosawa, S. Distinct renal pathology and a chemotactic phenotype after enterohemorrhagic Escherichia coli shiga toxins in non-human primate models of hemolytic uremic syndrome. Am. J. Pathol. 2013, 182, 1227-1238. [CrossRef] [PubMed]

93. Taylor, F.B., Jr.; Tesh, V.L.; DeBault, L.; Li, A.; Chang, A.C.; Kosanke, S.D.; Pysher, T.J.; Siegler, R.L. Characterization of the baboon responses to Shiga-like toxin: Descriptive study of a new primate model of toxic responses to Stx-1. Am. J. Pathol. 1999, 154, 1285-1299. [CrossRef]

94. Hellberg, A.; Westman, J.S.; Thuresson, B.; Olsson, M.L. P1PK: The blood group system that changed its name and expanded. Immunohematology 2013, 29, 25-33. [PubMed]

95. Kasai, K.; Galton, J.; Terasaki, P.I.; Wakisaka, A.; Kawahara, M.; Root, T.; Hakomori, S.I. Tissue distribution of the Pk antigen as determined by a monoclonal antibody. J. Immunogenet 1985, 12, 213-220. [CrossRef]

96. Ren, J.; Utsunomiya, I.; Taguchi, K.; Ariga, T.; Tai, T.; Ihara, Y.; Miyatake, T. Localization of verotoxin receptors in nervous system. Brain Res. 1999, 825, 183-188. [CrossRef]

97. Obata, F.; Tohyama, K.; Bonev, A.D.; Kolling, G.L.; Keepers, T.R.; Gross, L.K.; Nelson, M.T.; Sato, S.; Obrig, T.G. Shiga toxin 2 affects the central nervous system through receptor globotriaosylceramide localized to neurons. J. Infect. Dis. 2008, 198, 1398-1406. [CrossRef]

98. Wiels, J.; Fellous, M.; Tursz, T. Monoclonal antibody against a Burkitt lymphoma-associated antigen. Proc. Natl. Acad. Sci. USA 1981, 78, 6485-6488. [CrossRef]

99. Arvidsson, I.; Stahl, A.L.; Hedstrom, M.M.; Kristoffersson, A.C.; Rylander, C.; Westman, J.S.; Storry, J.R.; Olsson, M.L.; Karpman, D. Shiga toxin-induced complement-mediated hemolysis and release of complement-coated red blood cell-derived microvesicles in hemolytic uremic syndrome. J. Immunol. 2015, 194, 2309-2318. [CrossRef] 
100. Stahl, A.L.; Arvidsson, I.; Johansson, K.E.; Chromek, M.; Rebetz, J.; Loos, S.; Kristoffersson, A.C.; Bekassy, Z.D.; Morgelin, M.; Karpman, D. A novel mechanism of bacterial toxin transfer within host blood cell-derived microvesicles. PLoS Pathog. 2015, 11, e1004619. [CrossRef]

101. Noris, M.; Remuzzi, G. Hemolytic uremic syndrome. J. Am. Soc. Nephrol. 2005, 16, 1035-1050. [CrossRef]

102. Noris, M.; Remuzzi, G. Atypical hemolytic-uremic syndrome. N. Engl. J. Med. 2009, 361, 1676-1687. [CrossRef]

103. Keir, L.S.; Marks, S.D.; Kim, J.J. Shigatoxin-associated hemolytic uremic syndrome: Current molecular mechanisms and future therapies. Drug Des. Devel. Ther. 2012, 6, 195-208. [CrossRef]

104. Harkins, V.J.; McAllister, D.A.; Reynolds, B.C. Shiga-Toxin, E. coli Hemolytic Uremic Syndrome: Review of Management and Long-term Outcome. Curr. Pediatr. Rep. 2020, 8, 16-25. [CrossRef]

105. Mele, C.; Remuzzi, G.; Noris, M. Hemolytic uremic syndrome. Semin. Immunopathol. 2014, 36, 399-420. [CrossRef] [PubMed]

106. Furukawa, K.; Yokoyama, K.; Sato, T.; Wiels, J.; Hirayama, Y.; Ohta, M.; Furukawa, K. Expression of the Gb3/CD77 synthase gene in megakaryoblastic leukemia cells: Implication in the sensitivity to verotoxins. J. Biol. Chem. 2002, 277, 11247-11254. [CrossRef]

107. Ghosh, S.A.; Polanowska-Grabowska, R.K.; Fujii, J.; Obrig, T.; Gear, A.R. Shiga toxin binds to activated platelets. J. Thromb. Haemost 2004, 2, 499-506. [CrossRef] [PubMed]

108. Heyderman, R.S.; Soriani, M.; Hirst, T.R. Is immune cell activation the missing link in the pathogenesis of post-diarrhoeal HUS? Trends Microbiol. 2001, 9, 262-266. [CrossRef]

109. Beneke, J.; Sartison, A.; Kielstein, J.T.; Haller, H.; Nitschke, M.; Kunzendorf, U.; Loos, S.; Kemper, M.J.; Stahl, R.A.; Menne, J.; et al. Clinical and Laboratory Consequences of Platelet Transfusion in Shiga Toxin-Mediated Hemolytic Uremic Syndrome. Transfus. Med. Rev. 2017, 31, 51-55. [CrossRef]

110. Jinek, M.; Chylinski, K.; Fonfara, I.; Hauer, M.; Doudna, J.A.; Charpentier, E. A programmable dual-RNA-guided DNA endonuclease in adaptive bacterial immunity. Science 2012, 337, 816-821. [CrossRef]

111. Shalem, O.; Sanjana, N.E.; Hartenian, E.; Shi, X.; Scott, D.A.; Mikkelson, T.; Heckl, D.; Ebert, B.L.; Root, D.E.; Doench, J.G.; et al. Genome-scale CRISPR-Cas9 knockout screening in human cells. Science 2014, 343, 84-87. [CrossRef]

112. Wang, T.; Wei, J.J.; Sabatini, D.M.; Lander, E.S. Genetic screens in human cells using the CRISPR-Cas9 system. Science 2014, 343, 80-84. [CrossRef]

113. Pacheco, A.R.; Lazarus, J.E.; Sit, B.; Schmieder, S.; Lencer, W.I.; Blondel, C.J.; Doench, J.G.; Davis, B.M.; Waldor, M.K. CRISPR Screen Reveals that EHEC's T3SS and Shiga Toxin Rely on Shared Host Factors for Infection. mBio 2018, 9. [CrossRef] [PubMed]

114. Yamaji, T.; Sekizuka, T.; Tachida, Y.; Sakuma, C.; Morimoto, K.; Kuroda, M.; Hanada, K. A CRISPR Screen Identifies LAPTM4A and TM9SF Proteins as Glycolipid-Regulating Factors. iScience 2019, 11, 409-424. [CrossRef]

115. Majumder, S.; Kono, M.; Lee, Y.T.; Byrnes, C.; Li, C.; Tuymetova, G.; Proia, R.L. A genome-wide CRISPR/Cas9 screen reveals that the aryl hydrocarbon receptor stimulates sphingolipid levels. J. Biol. Chem. 2020, 295, 4341-4349. [CrossRef]

116. Kojima, Y.; Fukumoto, S.; Furukawa, K.; Okajima, T.; Wiels, J.; Yokoyama, K.; Suzuki, Y.; Urano, T.; Ohta, M.; Furukawa, K. Molecular cloning of globotriaosylceramide/CD77 synthase, a glycosyltransferase that initiates the synthesis of globo series glycosphingolipids. J. Biol. Chem. 2000, 275, 15152-15156. [CrossRef]

117. Keusch, J.J.; Manzella, S.M.; Nyame, K.A.; Cummings, R.D.; Baenziger, J.U. Cloning of Gb3 synthase, the key enzyme in globo-series glycosphingolipid synthesis, predicts a family of alpha 1, 4-glycosyltransferases conserved in plants, insects, and mammals. J. Biol. Chem. 2000, 275, 25315-25321. [CrossRef]

118. Yamaji, T.; Hanada, K. Sphingolipid metabolism and interorganellar transport: Localization of sphingolipid enzymes and lipid transfer proteins. Traffic 2015, 16, 101-122. [CrossRef] [PubMed]

119. Hogue, D.L.; Ellison, M.J.; Young, J.D.; Cass, C.E. Identification of a novel membrane transporter associated with intracellular membranes by phenotypic complementation in the yeast Saccharomyces cerevisiae. J. Biol. Chem. 1996, 271, 9801-9808. [CrossRef]

120. Cabrita, M.A.; Hobman, T.C.; Hogue, D.L.; King, K.M.; Cass, C.E. Mouse transporter protein, a membrane protein that regulates cellular multidrug resistance, is localized to lysosomes. Cancer Res. 1999, 59, 4890-4897. [PubMed]

121. Hogue, D.L.; Nash, C.; Ling, V.; Hobman, T.C. Lysosome-associated protein transmembrane 4 alpha (LAPTM4 alpha) requires two tandemly arranged tyrosine-based signals for sorting to lysosomes. Biochem. J. 2002, 365, 721-730. [CrossRef]

122. Milkereit, R.; Rotin, D. A role for the ubiquitin ligase Nedd4 in membrane sorting of LAPTM4 proteins. PLoS ONE 2011, 6, e27478. [CrossRef] [PubMed]

123. Jae, L.T.; Raaben, M.; Riemersma, M.; van Beusekom, E.; Blomen, V.A.; Velds, A.; Kerkhoven, R.M.; Carette, J.E.; Topaloglu, H.; Meinecke, P.; et al. Deciphering the glycosylome of dystroglycanopathies using haploid screens for lassa virus entry. Science 2013, 340, 479-483. [CrossRef]

124. Tanaka, A.; Tumkosit, U.; Nakamura, S.; Motooka, D.; Kishishita, N.; Priengprom, T.; Sa-Ngasang, A.; Kinoshita, T.; Takeda, N.; Maeda, Y. Genome-Wide Screening Uncovers the Significance of N-Sulfation of Heparan Sulfate as a Host Cell Factor for Chikungunya Virus Infection. J. Virol. 2017, 91. [CrossRef] [PubMed]

125. Tao, L.; Tian, S.; Zhang, J.; Liu, Z.; Robinson-McCarthy, L.; Miyashita, S.I.; Breault, D.T.; Gerhard, R.; Oottamasathien, S.; Whelan, S.P.J.; et al. Sulfated glycosaminoglycans and low-density lipoprotein receptor contribute to Clostridium difficile toxin A entry into cells. Nat. Microbiol. 2019, 4, 1760-1769. [CrossRef]

126. Meisen, W.H.; Nejad, Z.B.; Hardy, M.; Zhao, H.; Oliverio, O.; Wang, S.; Hale, C.; Ollmann, M.M.; Collins, P.J. Pooled Screens Identify GPR108 and TM9SF2 as Host Cell Factors Critical for AAV Transduction. Mol. Ther. Methods Clin. Dev. 2020, 17, 601-611. [CrossRef] 
127. Luteijn, R.D.; van Diemen, F.; Blomen, V.A.; Boer, I.G.J.; Manikam Sadasivam, S.; van Kuppevelt, T.H.; Drexler, I.; Brummelkamp, T.R.; Lebbink, R.J.; Wiertz, E.J. A Genome-Wide Haploid Genetic Screen Identifies Heparan Sulfate-Associated Genes and the Macropinocytosis Modulator TMED10 as Factors Supporting Vaccinia Virus Infection. J. Virol. 2019, 93. [CrossRef] [PubMed]

128. Foulquier, F.; Amyere, M.; Jaeken, J.; Zeevaert, R.; Schollen, E.; Race, V.; Bammens, R.; Morelle, W.; Rosnoblet, C.; Legrand, D.; et al. TMEM165 deficiency causes a congenital disorder of glycosylation. Am. J. Hum. Genet. 2012, 91, 15-26. [CrossRef]

129. Potelle, S.; Morelle, W.; Dulary, E.; Duvet, S.; Vicogne, D.; Spriet, C.; Krzewinski-Recchi, M.A.; Morsomme, P.; Jaeken, J.; Matthijs, G.; et al. Glycosylation abnormalities in Gdt1p/TMEM165 deficient cells result from a defect in Golgi manganese homeostasis. Hum. Mol. Genet. 2016, 25, 1489-1500. [CrossRef]

130. Dulary, E.; Potelle, S.; Legrand, D.; Foulquier, F. TMEM165 deficiencies in Congenital Disorders of Glycosylation type II (CDG-II): Clues and evidences for roles of the protein in Golgi functions and ion homeostasis. Tissue Cell 2017, 49, 150-156. [CrossRef]

131. Clark, C.R.; Maile, M.; Blaney, P.; Hellweg, S.R.; Strauss, A.; Durose, W.; Priya, S.; Habicht, J.; Burns, M.B.; Blekhman, R.; et al. Transposon mutagenesis screen in mice identifies TM9SF2 as a novel colorectal cancer oncogene. Sci. Rep. 2018, 8, 15327. [CrossRef] [PubMed]

132. Schimmoller, F.; Diaz, E.; Muhlbauer, B.; Pfeffer, S.R. Characterization of a $76 \mathrm{kDa}$ endosomal, multispanning membrane protein that is highly conserved throughout evolution. Gene 1998, 216, 311-318. [CrossRef]

133. Bergeret, E.; Perrin, J.; Williams, M.; Grunwald, D.; Engel, E.; Thevenon, D.; Taillebourg, E.; Bruckert, F.; Cosson, P.; Fauvarque, M.O. TM9SF4 is required for Drosophila cellular immunity via cell adhesion and phagocytosis. J. Cell Sci. 2008, 121, 3325-3334. [CrossRef]

134. Cornillon, S.; Pech, E.; Benghezal, M.; Ravanel, K.; Gaynor, E.; Letourneur, F.; Bruckert, F.; Cosson, P. Phg1p is a ninetransmembrane protein superfamily member involved in dictyostelium adhesion and phagocytosis. J. Biol. Chem. 2000, 275, 34287-34292. [CrossRef]

135. Pastan, I.; Hassan, R.; Fitzgerald, D.J.; Kreitman, R.J. Immunotoxin therapy of cancer. Nat. Rev. Cancer 2006, 6, 559-565. [CrossRef] [PubMed]

136. Antignani, A.; Fitzgerald, D. Immunotoxins: The role of the toxin. Toxins 2013, 5, 1486-1502. [CrossRef]

137. Oldham, R.A.A.; Faber, M.L.; Keppel, T.R.; Buchberger, A.R.; Waas, M.; Hari, P.; Gundry, R.L.; Medin, J.A. Discovery and validation of surface $\mathrm{N}$-glycoproteins in $\mathrm{MM}$ cell lines and patient samples uncovers immunotherapy targets. J. Immunother. Cancer 2020, 8. [CrossRef]

138. Fanale, M.A.; Hamlin, P.A.; Park, S.I.; Persky, D.O.; Higgins, J.P.; Burnett, C.; Dabovic, K.; Poma, E.; Sarapa, N.; Younes, A. Safety and efficacy of anti-CD20 immunotoxin MT-3724 in relapsed/refractory (R/R) B-cell non-Hodgkin lymphoma (NHL) in a phase I study. J. Clin. Oncol. 2018, 36, 7580. [CrossRef]

139. Higgins, J.P.; Iberg, A.; Howard, C.; Willert, E. Abstract 2060: Combination of CD20 targeted engineered toxin body, MT-3724, with chemotherapy or IMiDs for the treatment of non Hodgkin's lymphoma. Cancer Res. 2019, 79, 2060. [CrossRef]

140. Persky, D.O.; Musteata, V.; Zodelava, M.; Perekhrestenko, T.; Diaz, A.E.; Guthrie, T.H., Jr.; Strack, T.; Burnett, C.; Wilson, S.; Baetz, T. A Phase 2 Study of MT-3724 to Evaluate Safety, Pharmacodynamics and Efficacy of MT-3724 for the Treatment of Patients with Relapsed or Refractory Diffuse Large B-Cell Lymphoma. Blood 2019, 134, 5324. [CrossRef]

141. Erin, K.; Willert, G.L.R.; Jack, P.; Higgins, J.L.; Lee, J.; Syed, S.; Zhang, Y.; Tavares, D.; Lublinsky, A.; Chattopadhyay, N.; et al. TAK-169, an exceptionally potent CD38 targeted engineered toxin body, as a novel direct cell kill approach for the treatment of multiple myeloma [abstract]. In Proceedings of the American Association for Cancer Research Annual Meeting 2019, Atlanta, GA, USA, 29 March-3 April 2019; AACR: Philadelphia, PA, USA, 2019; Volume 79.

142. Kumar, S.K.; Cornell, R.F.; Landgren, O.; Ailawadhi, S.; Higgins, J.P.; Willert, E.K.; Waltzman, R.; Lin, J.; Zhang, Y.; Lublinsky, A.R.; et al. A Phase 1 First-in-Human Study of the Anti-CD38 Dimeric Fusion Protein TAK-169 for the Treatment of Patients (pts) with Relapsed or Refractory Multiple Myeloma (RRMM) Who Are Proteasome Inhibitor (PI)- and Immunomodulatory Drug (IMiD)-Refractory, Including Pts Relapsed/Refractory (R/R) or Naïve to Daratumumab (dara). Blood 2019, 134, 1867. [CrossRef]

143. Higgins, J.P.; Sarkar, A.; Williams, E.T.; Iberg, A.; Waltzman, R.; Willert, E.K. Abstract P1-18-35: MT-5111, a novel HER2 targeting engineered toxin body, under clinical development to overcome mechanisms of resistance to existing HER2 targeted therapies. Cancer Res. 2020, 80, P1-18-35-P11-18-35. [CrossRef]

144. Waltzman, R.J.; Sarkar, A.; Williams, E.T.; Iberg, A.T.; Higgins, J.T.; Willert, E.K. MT-5111: A novel HER2 targeting engineered toxin body in clinical development. J. Clin. Oncol. 2020, 38, 433. [CrossRef]

145. Waltzman, R.J.; Brieschke, B.; LeMar, S.; Dekker, J.; Cornelison, G.; Robinson, G.L.; Sarkar, A.; Zhao, J.; Iberg, A.T.; Ramos, H.J.; et al. PD-L1 targeted engineered toxin body provides direct cytotoxicity and T-cell mediated tumor targeting. J. Clin. Oncol. 2020, 38, 12. [CrossRef]

146. Ramos, H.J.; Brieschke, B.; LeMar, S.; Dekker, J.D.; Iberg, A.; Robinson, G.L.; Sarkar, A.; Anand, B.; Singh, M.M.; Zhao, J.; et al. Abstract 3366: In vivo efficacy of a PD-L1 targeted, antigen seeding engineered toxin body. Cancer Res. 2020, 80, 3366. [CrossRef]

147. Lee, R.S.; Tartour, E.; van der Bruggen, P.; Vantomme, V.; Joyeux, I.; Goud, B.; Fridman, W.H.; Johannes, L. Major histocompatibility complex class I presentation of exogenous soluble tumor antigen fused to the B-fragment of Shiga toxin. Eur. J. Immunol. 1998, 28, 2726-2737. [CrossRef]

148. Haicheur, N.; Bismuth, E.; Bosset, S.; Adotevi, O.; Warnier, G.; Lacabanne, V.; Regnault, A.; Desaymard, C.; Amigorena, S.; Ricciardi-Castagnoli, P.; et al. The B subunit of Shiga toxin fused to a tumor antigen elicits CTL and targets dendritic cells to allow MHC class I-restricted presentation of peptides derived from exogenous antigens. J. Immunol. 2000, 165, 3301-3308. [CrossRef] 
149. Haicheur, N.; Benchetrit, F.; Amessou, M.; Leclerc, C.; Falguieres, T.; Fayolle, C.; Bismuth, E.; Fridman, W.H.; Johannes, L.; Tartour, E. The B subunit of Shiga toxin coupled to full-size antigenic protein elicits humoral and cell-mediated immune responses associated with a Th1-dominant polarization. Int. Immunol. 2003, 15, 1161-1171. [CrossRef]

150. Choi, N.W.; Estes, M.K.; Langridge, W.H. Oral immunization with a shiga toxin B subunit: Rotavirus NSP4(90) fusion protein protects mice against gastroenteritis. Vaccine 2005, 23, 5168-5176. [CrossRef]

151. Vingert, B.; Adotevi, O.; Patin, D.; Jung, S.; Shrikant, P.; Freyburger, L.; Eppolito, C.; Sapoznikov, A.; Amessou, M.; QuintinColonna, F.; et al. The Shiga toxin B-subunit targets antigen in vivo to dendritic cells and elicits anti-tumor immunity. Eur. J. Immunol. 2006, 36, 1124-1135. [CrossRef]

152. Kordbacheh, E.; Nazarian, S.; Hajizadeh, A.; Fasihi-Ramandi, M.; Fathi, J. Recombinant HcpA-EspA-Tir-Stx2B chimeric protein induces immunity against attachment and toxicity of Escherichia coli O157:H7. Microb. Pathog. 2019, 129, 176-182. [CrossRef]

153. Yanina, H.; Romina, P.; Lucas, B.; Constanza, L.; Luciana, M.; Berengeno Andrea, L.; Mariana, C.; Ortega, H.; Goldbaum Fernando, A.; Santiago, S.; et al. Preclinical Studies of NEAST (Neutralizing Equine Anti-Shiga To xin): A Potential Treatment for Prevention of Stec-Hus. Int. J. Drug Dev. Res. 2019, 11. [CrossRef]

154. LaCasse, E.C.; Bray, M.R.; Patterson, B.; Lim, W.M.; Perampalam, S.; Radvanyi, L.G.; Keating, A.; Stewart, A.K.; Buckstein, R.; Sandhu, J.S.; et al. Shiga-like toxin-1 receptor on human breast cancer, lymphoma, and myeloma and absence from CD34(+) hematopoietic stem cells: Implications for ex vivo tumor purging and autologous stem cell transplantation. Blood 1999, 94, 2901-2910.

155. Johansson, D.; Kosovac, E.; Moharer, J.; Ljuslinder, I.; Brannstrom, T.; Johansson, A.; Behnam-Motlagh, P. Expression of verotoxin-1 receptor Gb3 in breast cancer tissue and verotoxin-1 signal transduction to apoptosis. BMC Cancer 2009, 9, 67. [CrossRef]

156. Stimmer, L.; Dehay, S.; Nemati, F.; Massonnet, G.; Richon, S.; Decaudin, D.; Klijanienko, J.; Johannes, L. Human breast cancer and lymph node metastases express $\mathrm{Gb3}$ and can be targeted by STxB-vectorized chemotherapeutic compounds. BMC Cancer 2014, 14, 916. [CrossRef] [PubMed]

157. Arab, S.; Russel, E.; Chapman, W.B.; Rosen, B.; Lingwood, C.A. Expression of the verotoxin receptor glycolipid, globotriaosylceramide, in ovarian hyperplasias. Oncol. Res. 1997, 9, 553-563. [PubMed]

158. Heath-Engel, H.M.; Lingwood, C.A. Verotoxin sensitivity of ECV304 cells in vitro and in vivo in a xenograft tumour model: VT1 as a tumour neovascular marker. Angiogenesis 2003, 6, 129-141. [CrossRef]

159. Maak, M.; Nitsche, U.; Keller, L.; Wolf, P.; Sarr, M.; Thiebaud, M.; Rosenberg, R.; Langer, R.; Kleeff, J.; Friess, H.; et al. Tumorspecific targeting of pancreatic cancer with Shiga toxin B-subunit. Mol. Cancer Ther. 2011, 10, 1918-1928. [CrossRef]

160. Kovbasnjuk, O.; Mourtazina, R.; Baibakov, B.; Wang, T.; Elowsky, C.; Choti, M.A.; Kane, A.; Donowitz, M. The glycosphingolipid globotriaosylceramide in the metastatic transformation of colon cancer. Proc. Natl. Acad. Sci. USA 2005, 102, 19087-19092. [CrossRef]

161. Falguieres, T.; Maak, M.; von Weyhern, C.; Sarr, M.; Sastre, X.; Poupon, M.F.; Robine, S.; Johannes, L.; Janssen, K.P. Human colorectal tumors and metastases express Gb3 and can be targeted by an intestinal pathogen-based delivery tool. Mol. Cancer Ther. 2008, 7, 2498-2508. [CrossRef]

162. Farkas-Himsley, H.; Hill, R.; Rosen, B.; Arab, S.; Lingwood, C.A. The bacterial colicin active against tumor cells in vitro and in vivo is verotoxin 1. Proc. Natl. Acad. Sci. USA 1995, 92, 6996-7000. [CrossRef]

163. Geyer, P.E.; Maak, M.; Nitsche, U.; Perl, M.; Novotny, A.; Slotta-Huspenina, J.; Dransart, E.; Holtorf, A.; Johannes, L.; Janssen, K.P. Gastric Adenocarcinomas Express the Glycosphingolipid Gb3/CD77: Targeting of Gastric Cancer Cells with Shiga Toxin B-Subunit. Mol. Cancer Ther. 2016, 15, 1008-1017. [CrossRef] [PubMed]

164. Salhia, B.; Rutka, J.T.; Lingwood, C.; Nutikka, A.; Van Furth, W.R. The treatment of malignant meningioma with verotoxin. Neoplasia 2002, 4, 304-311. [CrossRef]

165. Couture, O.; Dransart, E.; Dehay, S.; Nemati, F.; Decaudin, D.; Johannes, L.; Tanter, M. Tumor delivery of ultrasound contrast agents using Shiga toxin B subunit. Mol. Imaging 2011, 10, 135-143. [CrossRef] [PubMed]

166. Li, Q.Y.; Tang, J.; He, E.H.; Li, Y.M.; Zhou, Y.; Zhang, X.; Chen, G. Clinical utility of three-dimensional contrast-enhanced ultrasound in the differentiation between noninvasive and invasive neoplasms of urinary bladder. Eur. J. Radiol. 2012, 81, 2936-2942. [CrossRef]

167. Nicolau, C.; Bunesch, L.; Peri, L.; Salvador, R.; Corral, J.M.; Mallofre, C.; Sebastia, C. Accuracy of contrast-enhanced ultrasound in the detection of bladder cancer. Br. J. Radiol. 2011, 84, 1091-1099. [CrossRef]

168. Tarrago-Trani, M.T.; Jiang, S.; Harich, K.C.; Storrie, B. Shiga-like toxin subunit B (SLTB)-enhanced delivery of chlorin e6 (Ce6) improves cell killing. Photochem. Photobiol. 2006, 82, 527-537. [CrossRef]

169. El Alaoui, A.; Schmidt, F.; Amessou, M.; Sarr, M.; Decaudin, D.; Florent, J.C.; Johannes, L. Shiga toxin-mediated retrograde delivery of a topoisomerase I inhibitor prodrug. Angew. Chem. Int. Ed. Engl. 2007, 46, 6469-6472. [CrossRef]

170. El Alaoui, A.; Schmidt, F.; Sarr, M.; Decaudin, D.; Florent, J.C.; Johannes, L. Synthesis and properties of a mitochondrial peripheral benzodiazepine receptor conjugate. ChemMedChem 2008, 3, 1687-1695. [CrossRef]

171. Batisse, C.; Dransart, E.; Ait Sarkouh, R.; Brulle, L.; Bai, S.K.; Godefroy, S.; Johannes, L.; Schmidt, F. A new delivery system for auristatin in STxB-drug conjugate therapy. Eur. J. Med. Chem. 2015, 95, 483-491. [CrossRef]

172. Kostova, V.; Dransart, E.; Azoulay, M.; Brulle, L.; Bai, S.K.; Florent, J.C.; Johannes, L.; Schmidt, F. Targeted Shiga toxin-drug conjugates prepared via Cu-free click chemistry. Bioorg. Med. Chem. 2015, 23, 7150-7157. [CrossRef] 
173. Ryou, J.H.; Sohn, Y.K.; Hwang, D.E.; Kim, H.S. Shiga-like toxin-based high-efficiency and receptor-specific intracellular delivery system for a protein. Biochem. Biophys. Res. Commun. 2015, 464, 1282-1289. [CrossRef]

174. Mohammed, A.F.; Abdul-Wahid, A.; Huang, E.H.; Bolewska-Pedyczak, E.; Cydzik, M.; Broad, A.E.; Gariepy, J. The Pseudomonas aeruginosa exotoxin A translocation domain facilitates the routing of CPP-protein cargos to the cytosol of eukaryotic cells. J. Control. Release 2012, 164, 58-64. [CrossRef]

175. Ryou, J.H.; Sohn, Y.K.; Hwang, D.E.; Park, W.Y.; Kim, N.; Heo, W.D.; Kim, M.Y.; Kim, H.S. Engineering of bacterial exotoxins for highly efficient and receptor-specific intracellular delivery of diverse cargos. Biotechnol. Bioeng. 2016, 113, 1639-1646. [CrossRef] [PubMed]

176. Ryou, J.H.; Sohn, Y.K.; Kim, D.G.; Kyeong, H.H.; Kim, H.S. Engineering and cytosolic delivery of a native regulatory protein and its variants for modulation of ERK2 signaling pathway. Biotechnol. Bioeng. 2018, 115, 839-849. [CrossRef] [PubMed]

177. Schmit, N.E.; Neopane, K.; Hantschel, O. Targeted Protein Degradation through Cytosolic Delivery of Monobody Binders Using Bacterial Toxins. ACS Chem. Biol. 2019, 14, 916-924. [CrossRef]

178. Du, J.; Jin, J.; Yan, M.; Lu, Y. Synthetic nanocarriers for intracellular protein delivery. Curr. Drug Metab. 2012, 13, 82-92. [CrossRef]

179. Frank, C.; Werber, D.; Cramer, J.P.; Askar, M.; Faber, M.; an der Heiden, M.; Bernard, H.; Fruth, A.; Prager, R.; Spode, A.; et al. Epidemic profile of Shiga-toxin-producing Escherichia coli O104:H4 outbreak in Germany. N. Engl. J. Med. 2011, 365, 1771-1780. [CrossRef] 